\section{OAK RIDGE \\ NATIONAL LABORATORY}

MANAGED BY UT-BATTELLE

FOR THE DEPARTMENT OF ENERGY

\title{
Shipping Cask Studies with MOX Fuel
}

\author{
A. M. Pavlovichev \\ Project Manager \\ A. I. Osadchy \\ V. I. Brysgalov \\ E. A. Gomin \\ M. A. Kalugin \\ V. V. Tebin \\ V. N. Muhachev \\ A. G. Khohlov \\ G. N. Khohlov \\ A. G. Tsikounov
}

Russian Research Center "Kurchatov Institute"

A Russian Contribution to the

Fissile Materials Disposition Program

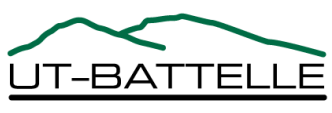




\section{DOCUMENT AVAILABILITY}

Reports produced after January 1,1996 , are generally available free via the U.S. Department of Energy (DOE) Information Bridge.

Web site http://www.osti.gov/bridge

Reports produced before January 1, 1996, may be purchased by members of the public from the following source.

National Technical Information Service

5285 Port Royal Road

Springfield, VA 22161

Telephone 703-605-6000 (1-800-553-6847)

TDD 703-487-4639

Fax 703-605-6900

E-mail info@ntis.fedworld.gov

Web site http://www.ntis.gov/support/ordernowabout.htm

Reports are available to DOE employees, DOE contractors, Energy Technology Data Exchange (ETDE) representatives, and International Nuclear Information System (INIS) representatives from the following source.

Office of Scientific and Technical Information

P.O. Box 62

Oak Ridge, TN 37831

Telephone 865-576-8401

Fax 865-576-5728

E-mail reports@adonis.osti.gov

Web site http://www.osti.gov/contact.html

This report was prepared as an account of work sponsored by an agency of the United States Government. Neither the United States Government nor any agency thereof, nor any of their employees, makes any warranty, express or implied, or assumes any legal liability or responsibility for the accuracy, completeness, or usefulness of any information, apparatus, product, or process disclosed, or represents that its use would not infringe privately owned rights. Reference herein to any specific commercial product, process, or service by trade name, trademark, manufacturer, or otherwise, does not necessarily constitute or imply its endorsement, recommendation, or favoring by the United States Government or any agency thereof. The views and opinions of authors expressed herein do not necessarily state or reflect those of the United States Government or any agency thereof. 


\title{
SHIPPING CASK STUDIES WITH MOX FUEL
}

\author{
A. M. Pavlovichev \\ Project Manager
}
A. I. Osadchy
M. A. Kalugin
A. G. Khohlov
V. I. Brysgalov
V. V. Tebin
G. N. Khohlov
E. A. Gomin
V. N. Muhachev
A. G. Tsikounov

Date Published: May 2001

\author{
Prepared by \\ Russian Research Center "Kurchatov Institute" \\ Institute of Nuclear Reactors \\ under subcontract 85B-99398V \\ Funded by \\ Office of Fissile Materials Disposition \\ U.S. Department of Energy \\ Prepared for \\ Computational Physics and Engineering Division \\ OAK RIDGE NATIONAL LABORATORY \\ Oak Ridge, Tennessee 37831 \\ managed by \\ UT-BATTELLE, LLC \\ for the \\ U.S. DEPARTMENT OF ENERGY \\ under contract DE-AC05-00OR22725
}


Russian Research Center "Kurchatov Institute" Institute of Nuclear Reactors

VVER Division

State Scientific Centre of the Russian Federation Leipunski Institute for Physics and Power Engineering

Joint U.S. / Russian Project to Update, Verify and Validate Reactor Design/Safety Computer Codes Associated with Weapons-Grade Plutonium Disposition in WVER Reactors

\section{Shipping Cask Studies with MOX Fuel}

General Order 85B-99398V. Work Release KI-WR04RTP. P. 00-6a

(Final Report)

Project Manager

A.M.Pavlovitchev

Moscow 2000 
Document consists of 2 parts that consider correspondingly problems of nuclear and radiation safety in transportation operations at a VVER-1000 NPP with 3 MOX LTAs particularly at Balakovo-4. In the presented final report the supplemental cases of eventual fresh MOX LTAs location in a transportation in-plant jacket have been considered. 


\title{
Part 1
}

Nuclear Safety

Executed by

\author{
A.I.Osadchy \\ V.I.Brysgalov \\ E.A.Gomin \\ M.A.Kalugin \\ V.V.Tebin \\ V.N.Muhachev
}




\section{Abbreviation}

BV - cooling pool (non-compact)

FA - fuel assembly

MOX - mixed uranium-plutonium fuel

NPP - nuclear power plant

UBV - compact cooling pool

UOX - uranium-oxide fuel

VVER - water cooled water moderated power reactor 


\section{Abstract}

Tasks of nuclear safety assurance for storage and transport of fresh mixed uraniumplutonium fuel of the VVER-1000 reactor are considered in the view of 3 MOX LTAs introduction into the core. The precise code MCU that realizes the Monte Carlo method is used for calculations. 


\section{Contents}

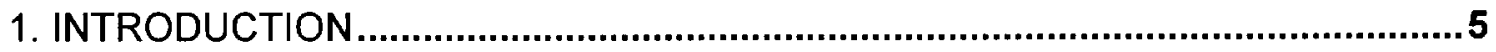

2. MEANS FOR TRANSPORT AND STORAGE OF FRESH FUEL AT WVR-1000

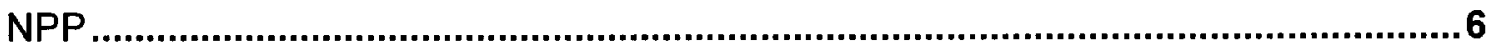

3. PHYSICAL FEATURES OF CRITICALITY TASK IN FUEL TRANSPORT AND STORAGE EQUIPMENT AND BRIEF DESCRIPTION OF THE CODE MCU-RFFI/A7

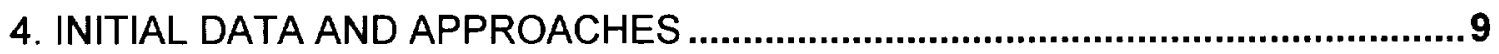

5. CRITICALITY IN FACILITIES FOR FUEL STORAGE AND TRANSPORT ............11

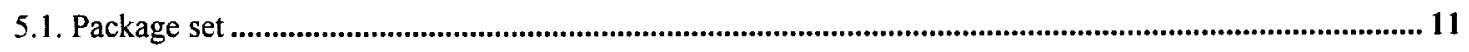

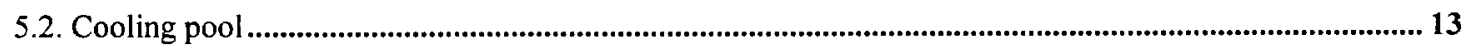

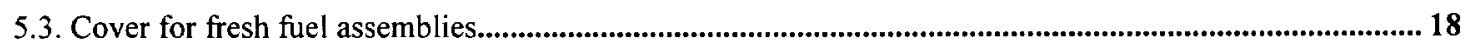

6. 3 LTAS INTRODUCTION IN WER-1000 AND TRANSPORTATION PROBLEMS19

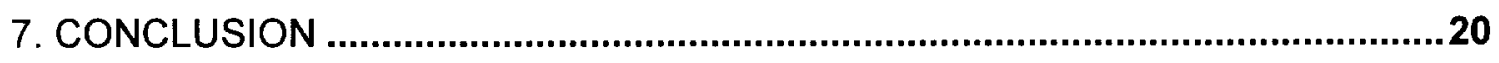

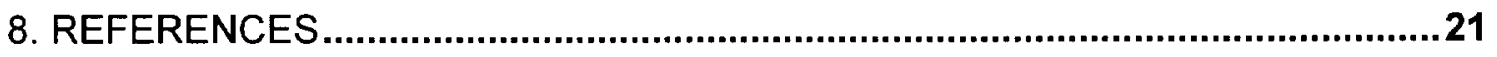




\section{Introduction}

Actually in Russia the principle of direct replacement of uranium fuel by MOX fuel is being applied while designing VVER-1000 fuel cycles with partial loading by weapons-grade MOX fuel. FA design is not noticeably modified. Particularly, in fuel cycle with $1 / 3$ MOX core [1] MOX FA design is identical to that of advanced uranium fuel cycle with Zirconium guide tubes and space grids. Fuel pins with uranium-gadolinium fuel, tested in UOX FAs, are used in MOX FAs as burnable poison rods. Taking into account an equivalence of UOX and MOX FAs design, the use of the existing NPP equipment for MOX FAs transport and storage is considered in present studies.

Fresh MOX FAs in comparison with UOX ones possess the following features as applying to transport and storage tasks:

- availability of a set of plutonium isotopes with fission and absorption cross sections substantially different from U-235 ones,

- increased radioactivity of MOX fuel,

- eventual positive void effect if considerable Pu concentration in MOX fuel.

In present work the studies of nuclear safety in transportation and storage at VVER1000 NPP with MOX fuel are performed. Initial data and safety criteria are formulated according to "Safety rules for nuclear fuel storage and transport at the nuclear engineering object" [2]. The calculations are performed by the precise code MCU-RFFI/A [3], using Monte Carlo method and neutron libraries formed on the base of estimated nuclear data. The results obtained for UOX and MOX fuel are compared. 


\section{Means for transport and storage of fresh fuel at WVR-1000 NPP}

Fresh fuel assemblies are transported from the production plant to NPP by means of the railway in special package sets. The package set consists of two tubes positioned in parallel and welded on to the interlayer. The ends of the pipes have nozzles covered by removable lids. There is a wooden container in the each tube that holds the fuel assembly. The package set is intended for two FAs location.

Storage of uranium FAs at NPP Fresh Fuel Depository is performed either in package sets stacks or in decks or in the covers for fresh fuel. MOX fuel storage is supposed to perform in package sets avoiding an excessive radiation in comparison with other types of storage.

Fuel assembly transport from the fresh fuel depository to the reactor hall is performed in the covers for fresh fuel. The cover for fresh fuel is intended for transport of 18 fuel assemblies placed vertically. The fuel assemblies may be loaded from the cover directly into reactor or if necessary - into cooling pool.

The cooling pool is intended for holding the irradiated fuel assemblies for the time necessary for decrease of residual heat to the values, which allow transportation of spent fuel from NPP. According to the initial Technical project of VVER-1000 NPP, the FAs are placed in non-compact decks. The cooling pool sub-criticality is ensured by the choice of their positioning pitch in the water. This type of positioning of fuel assemblies provide 3 years storage of irradiated fuel assemblies and possibility for emergency unloading of the core at any moment. Recently cooling pools at some VVER-1000 units have been modernized (for example Balakovo 4) by means of the decks for close or compact fuel storage (SUHT) with the use of hexagonal tubes made of borated steel. Such technical decision, which realizes the principle of combined neutron "trap", increased the storage capacity of the decks' lattice 1.8 times and provided sub-criticality for uranium fuel in the accidental regimes while coolant density lowering. 


\section{Physical features of criticality task in fuel transport and storage equipment and brief description of the code MCU-RFFI/A}

Keff $\approx 1.4$ for physically big array without gaps of VVER-1000 FAs with $4.4 \%$ enrichment (the enrichment of make-up fuel) filled with water without absorber dissolved in it. Such large value of Keff requires special measures to provide nuclear safety of fuel storage and transport. These measures are realized in constructions of facilities to treat fresh and irradiated fuel and in organizational and technical means.

FAs are placed with a distance (gap between FA $\sim 15 \mathrm{~cm}$ ) between them and in some cases absorbers are placed between FAs (storage SUHT) to provide sub-criticality in the means to treat the fuel. These peculiarities of FAs placement in the storage and transport facilities together with the necessity while calculating to change water density, boric acid concentration and geometry in accidental situations stand for physical peculiarity of the task, and distinguish them from traditional tasks of VVER core calculation.

Physical nature of the neutron moderation and diffusion in fuel transport and storage equipment is as follows:

- part of the neutrons that were born in FA (fission spectrum) moderates inside the FA, the other part (approximately equal to the ratio of gaps volumes between fuel assemblies and overall water volume) moderates in gaps without any noticeable absorption;

- the existence of strong scattering anisotropy in hydrogen leads to the predomination of fast neutron diffusion to the gap;

- thermal neutron density in the gap is significantly higher than the density in FA itself, this leads to predomination of thermal neutron diffusion from the gap to the fuel (it is also necessary to take into account scattering anisotropy correctly to calculate criticality in this case);

- the existence of the cover absorbers from boric steel (in SUHT) with strong absorption leads to the non-monotonous neutron distribution function near the FA-to-gap border.

Thus, the criticality calculations require, on the one hand, to take into account scattering anisotropy, which is common for neutron radiation protection tasks; on the other hand, to use detailed space and energy grid, which is common for cells calculations by means of precision methodologies.

The codes using Monte Carlo methods with libraries from estimated neutron data files meet these requirements.

MCU-RFFV/A [3] allows the user to calculate effective multiplication factor Keff and flux functionals in the neutron multiplying systems. The MCU-RFFI/A code is intended to solve the neutron transport equation by means of the Monte Carlo method using estimated nuclear data for systems with arbitrary three-dimensional geometry. The code allows the user to solve both homogeneous (criticality) and non-homogeneous (outer source) tasks. The code allows three-dimensional tasks with different border conditions: leakage through outer surface, white and mirror reflections, translational symmetry.

Subgroup approximation or Bondarenko f-factors are used to take into account crosssections shielding in the region of unresolved resonances. Besides, pointwise description of cross-sections is allowed for the region of resolved resonances; in this case cross-sections of the most important nuclides are described by "infinite" number of points, because they are calculated by means of analytical formulae based on resonance parameters for each energy point during modeling. Such scheme allows the user to perform calculations at any temperature without preliminary preparation of cross-sections table. 
The DLC/MCUDAT-1.0 neutron physic data base is the data support for the MCURFFI/A code. DLC/MCUDAT-1.0 includes:

$\mathrm{BNAB} / \mathrm{MCU}$ - enlarged and modified version of 26-group constant system BNAB,

LIPAR - resonance parameters in the resolved resonance region,

TEPCON - multy-group cross-sections in the thermalization region,

VESTA - the library for modeling of neutron collisions with nucleus taking into account continuous change of neutron's energy in the thermalization region, that is given in the form of the probability tables obtained from scattering laws $S(\alpha, \beta)$.

DLC/MCUDAT-1.0 and the code are verified for main nuclides using the data of more than 400 integral benchmark experiments. The precision of Keff calculations is comparable to the experimental one.

The MCU-RFFV/A code allows one to calculate three-dimensional systems practically of any complication. The systems are described by means of combinatorial geometry as Boolean combinations of primitive bodies. The user has a choice of 13 types of bodies (cylinder, cone, sphere, parallelepiped and etc.). The possibility of using the symmetry of the system and lattices - that are generated by means of multiplication of some of the initial elements - makes it easier to describe the geometry and border conditions. The lattices may include heterogeneity.

The functionals are determined as flux integrals with given weight functions in registration zones, registration objects, and the system as a whole. The borders of registrational energy groups for integration over the energy are set by the user.

The following values are calculated:

- neutron multiplication factor (by the number of collisions, number of absorbtions, combined estimations),

- neutron flux density,

- nuclear reaction rates for separate nuclides and their mixture in the given spaceenergy intervals,

- few-group constant set for registration objects,

- effective fraction of delayed neutrons. 


\section{Initial data and approaches}

Main characteristics of UOX and MOX FAs, used in VVER-1000 fuel cycles with $1 / 3$ MOX core, are presented in [1]. Maximal enrichment on U-235 of UOX FAs is equal to $4.08 \%$. Contents of $\mathrm{U}^{235}, \mathrm{Pu}^{239}, \mathrm{Pu}^{240}$ and $\mathrm{Pu}^{241}$ in MOX FAs equal correspondingly to $0.200 \%, 3.190 \%, 0.206 \%$ and $0.034 \%$. $\mathrm{Zr}$ is used as a FA construction material, UOX fuel pin weight is $1.575 \mathrm{~kg}$, MOX one is $1.600 \mathrm{~kg}$. 6 and 18 pins with uranium-gadolinium fuel are placed correspondingly in UOX and MOX FAs.

According to the requirements of "Safety rules for nuclear fuel storage and transport at the nuclear engineering object" [2] the presented nuclear safety calculations were performed using the following conservatism:

- Fresh UOX and MOX FAs are considered without integrated burnable poisons in FAs;

- $\mathrm{Pu}^{239}$ content is increased, $\mathrm{Pu}^{240}$ one is decreased in comparison with [1] MOX FA;

- $\mathrm{Pu}^{241}$ is taken into account by additional increase of $\mathrm{Pu}^{239}$ content;

- Water distributions, leading to maximal effective multiplication factor in the means of transport and storage, are considered;

- Zero boron concentration in water is considered;

- As a rule infinite fuel systems without leakage are considered;

- Auxiliary steel construction elements with strong neutron absorption are not considered.

Taking into account the above-mentioned, the conservative options of UOX and MOX FAs design have been defined (See Table 4.1) and have been used in nuclear safety calculations for the means of transport and storage.

According to the "Safety rules..." [2] the effective multiplication factor in the means of transport and storage during normal operation and in accidental regimes is limited by the value 0.95 . 
Table 4.1. Main FA characteristics in nuclear safety calculations

\begin{tabular}{|l|c|c|}
\hline \multirow{2}{*}{ Characteristic } & \multicolumn{2}{|c|}{ Value } \\
\cline { 2 - 3 } & UOX FA & MOX FA \\
\hline Width across flats, mm & 234 & 234 \\
\hline $\begin{array}{l}\text { Number of fuel pins (rods) in FA, } \\
\text { items }\end{array}$ & 312 & 312 \\
\hline $\begin{array}{l}\text { Number of uranium-gadolinium } \\
\text { burnable poison rods in FA, items }\end{array}$ & - & - \\
\hline Pitch between rod and rod, mm & 12.75 & 12.75 \\
\hline $\begin{array}{l}\text { Number of guide channels for } \\
\text { control rods, items }\end{array}$ & 18 & 18 \\
\hline Number of space grids, items & 15 & 15 \\
\hline $\begin{array}{l}\text { Material of space grids, guide } \\
\text { channels and central tubes }\end{array}$ & $\mathrm{Zr}+1 \% \mathrm{Nb}$ & $\mathrm{Zr}+1 \% \mathrm{Nb}$ \\
\hline Rod cladding diameter, mm & $9.1 \times 0,69$ & $9.1 \times 0,69$ \\
\hline Diameter of guide channels, mm & $13.0 \times 1.0$ & $13.0 \times 1.0$ \\
\hline Diameter of central tube, mm & $13.0 \times 1.0$ & $13.0 \times 1.0$ \\
\hline Height of fuel column, mm & 3530 & 3530 \\
\hline Contents of U-235 in the fuel, \% & 4.400 & 0.200 \\
\hline Contents of Pu-239 in the fuel, \% & - & 4.200 \\
\hline Contents of Pu-240 in the fuel, \% & - & 0.175 \\
\hline Contents of Pu-241 in the fuel, \% & - & - \\
\hline Mass of fuel in rod, kg & $1.460 *$ & 1.600 \\
\hline
\end{tabular}

* U-235 mass in fuel rods corresponds to U-235 mass in UOX FAs described in [1]. 


\section{Criticality in facilities for fuel storage and transport}

\subsection{Package set}

Calculational model of the package set is given in the figure 5.1. Cell vertical dimension is $550 \mathrm{MM}$, horizontal one is $620 \mathrm{MM}$. In axial direction cell size is infinite.

Table 5.1 presents Keff values for infinite lattice of FA (with UOX and MOX fuel) placed into package sets. Calculations have been performed for normal operation ("dry" package set) and for accidental regimes with cold water without boron both inside and outside the package set.

Table 5.1 Multiplication factors in infinite grid of package set cells with UOX and MOX FAs

\begin{tabular}{|l|c|c|}
\hline \multicolumn{1}{|c|}{ Regime } & UOX FA & MOX FA \\
\hline «Dry» package set & $0,827(2)$ & $0,855(2)$ \\
\hline Cold water both inside and outside the package set & $0.839(2)$ & $0.848(2)$ \\
\hline
\end{tabular}

As it is seen from the presented results, nuclear safety is ensured under normal operation and principal accident.

Additionally the variant with infinite grid of package sets has been considered where cold water is found only inside the set and not outside. In this case the effective multiplication factor is equal to 1.063 (2) and 1.075 (2) correspondingly for UOX and MOX FAs. The limiting effective multiplication factor value $($ Keff $<0.95$ ) in this case of water distribution is ensured for package sets location in 4 rows without limitation in width. 


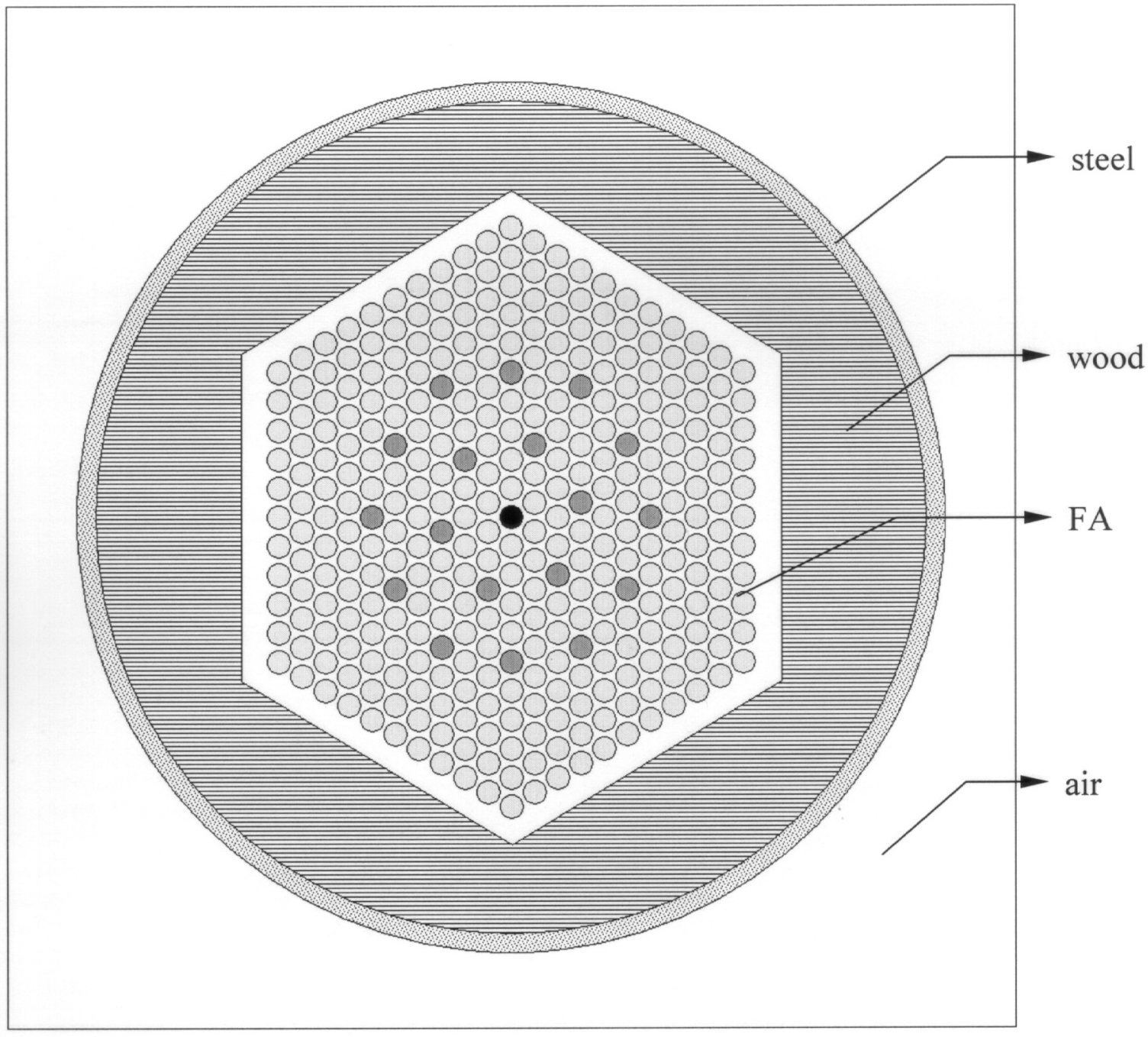

Fig. 5.1 Calculational model of package set cell 


\subsection{Cooling pool}

Calculational models for both closed (compact) and not closed (non-compact) cooling pool are given in figure 5.2. Infinite grid of cells has been considered in calculations to ensure, according to "Safety rules..." [2], conservative estimation of maximal design capacity of storage and of radial reflector influence. In axial direction a calculational model dimension has been supposed unlimited except of some cases mentioned in the text.

Dependence of the effective multiplication factor on placement pitch of UOX and MOX fuel assemblies in compact and non-compact cooling pools is given at the figure 5.3. Coolant density corresponds to a cold state, boron acid in current is absent. The curves concern UOX FAs, a set of points concerns MOX FAs. The results show that the effective multiplication factors of UOX and MOX Fas are close for all pitch values.

For design cell dimensions of compact and non-compact cooling pools (correspondingly 300 and $400 \mathrm{~mm}$ ) and under normal operation conditions the effective multiplication factor is less then 0.95 both for UOX FA and MOX FA.

$\mathrm{Pu}^{240}$ content significantly influences the MOX FA multiplication factor in a cooling pool. If it decreases from $4 \%$ till 0 , the effective multiplication factor increases of about $4 \%$ but the limiting subcriticality value $5000 \mathrm{pcm}$ is still ensured.

Figure 5.4 presents Keff values for accidental regimes with the decrease of water density. The curves concern Keff evolution for UOX FAs, corresponding dependencies for MOX FAs are described by a set of points. Dotted lines correspond to a non-compact cooling pool with and without axial neutron leakage. The presented results show that Keff increasing takes place in non-compact cooling pools for coolant densities lower than $0.7 \mathrm{~g} / \mathrm{cm}^{3}$ and Keff is over 0.95 for the densities lower than $0.5 \mathrm{~g} / \mathrm{cm}^{3}$. If no neutron leakage, Keff increasing continues till the density of about $0.1 \mathrm{~g} / \mathrm{cm}^{3}$ and after that it is seen the strong drop of Keff. For empty (without water) non-compact cooling pool the calculations give Keff $=0.689$ for UOX FAs and Keff $=0.733$ for MOX FAs. If axial neutron leakage is taken into account, Keff significantly decreases for low coolant densities.

So the subcriticality values meet requirements in a non-compact cooling pool without boron in coolant for the coolant densities in the interval of $0.5-1.0 \mathrm{~g} / \mathrm{cm}^{3}$ and also for the densities close to 0 .

The curves and corresponding points in Fig.5.4 describe effective multiplication factor dependencies on water density for a compact cooling pool. The upper curve corresponds to the 
case of water density decreasing in a whole pool, the lower one - to water density decreasing only inside of hexagonal tubes. The presented results show that Keff decreases in a compact cooling pool both for traditional uranium fuel and MOX fuel. If no water in a compact cooling pool, Keff values are 0.589 and 0.604 correspondingly for UOX and MOX FAs. So a cooling pool with compact decks of fuel storage ensures a significant capacity increase, meet subcriticality requirements for MOX and UOX FAs both under normal operation conditions and accidental situations with water density decreasing. 


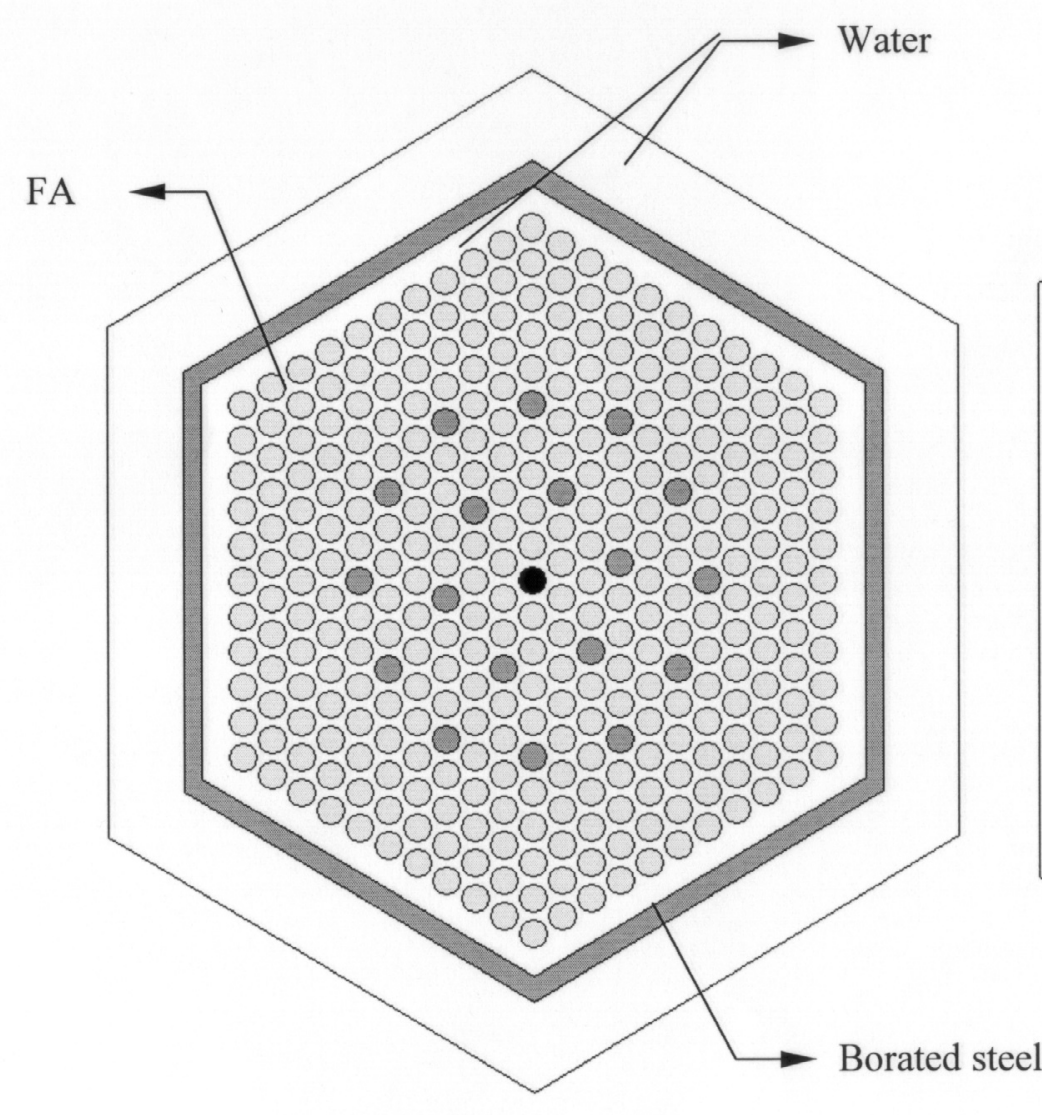

Compact cooling pool

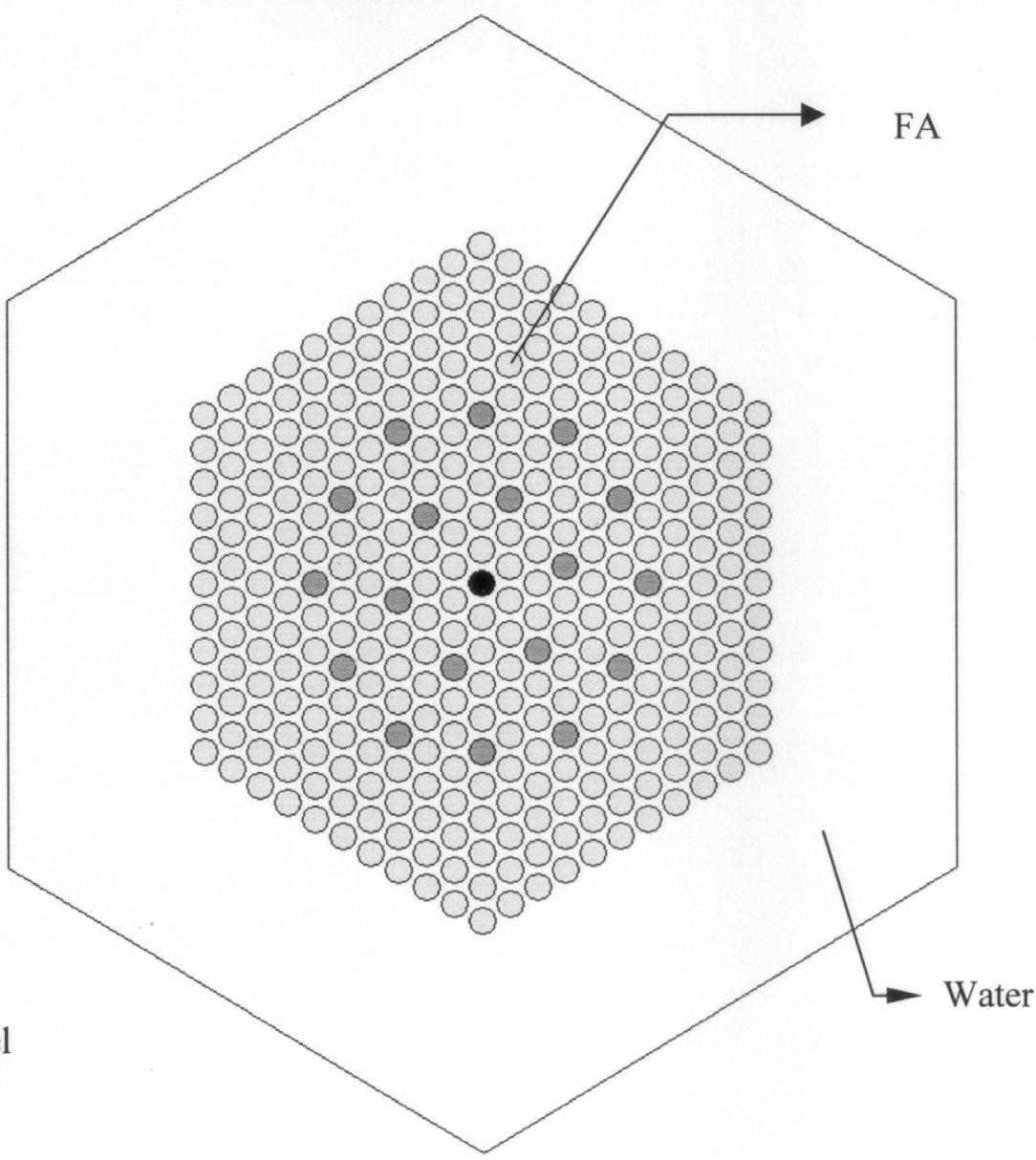

Non-compact cooling pool

Fig. 5.2 Calculational cell models for compact and non-compact cooling pools 


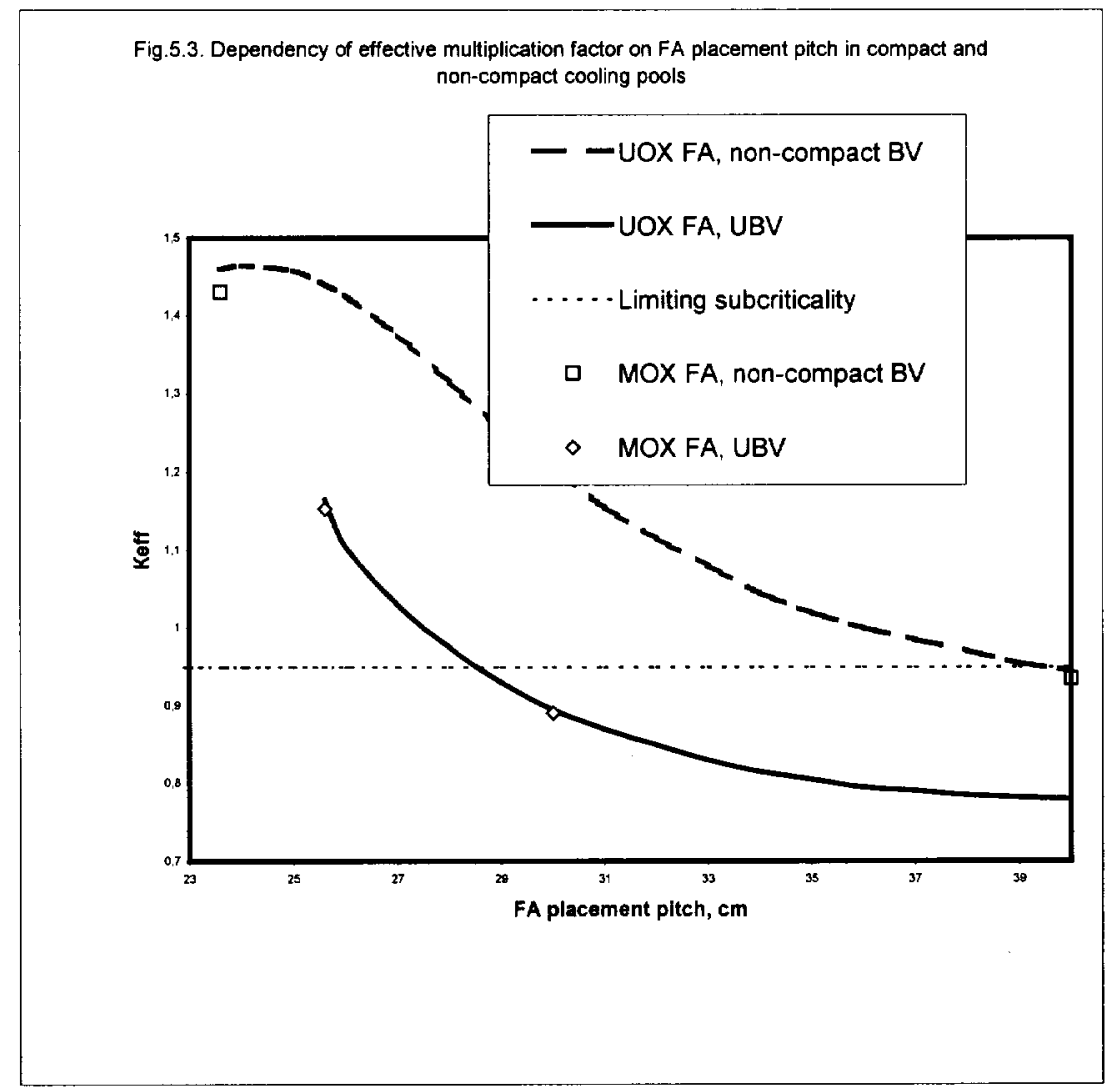

RRC "Kurchatov Institute" 


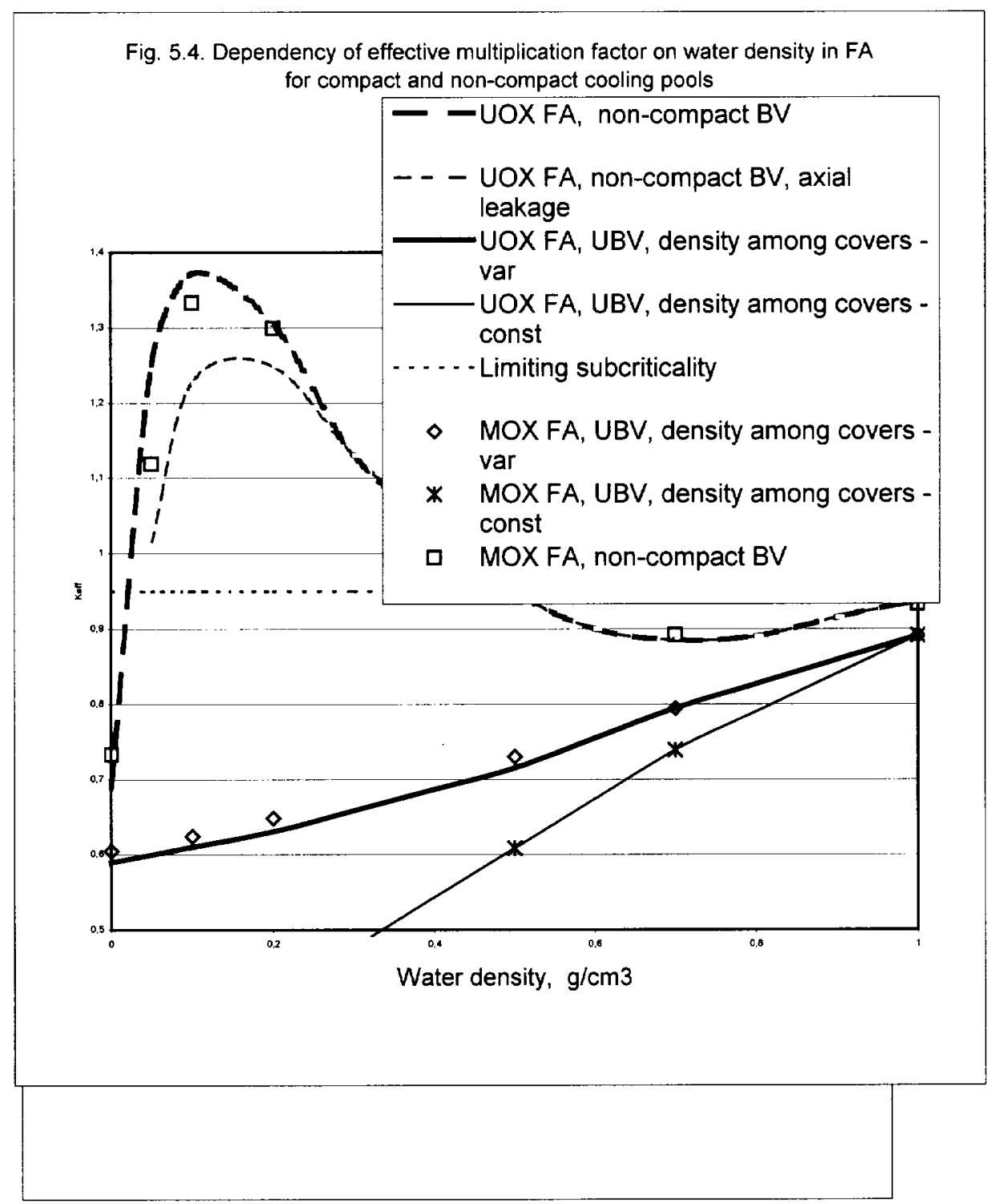




\subsection{Cover for fresh fuel assemblies}

Cover for fresh FAs is intended for FAs storage and transport at NPPs. 18 fresh FAs are positioned in a cover with a pitch of $400 \mathrm{~mm}$ corresponding to the pitch in a non-compact cooling pool. So the results presented in p.5.2 for a non-compact cooling pool can be considered as conservative estimations for cover subcriticality. According to the presented in p.5.2 results, subcriticlity of a cover with MOX FAs is ensured for water densities about 0 and for water densities in the interval $0.5-1.0$ $\mathrm{g} / \mathrm{cm}^{3}$. It is evident that if the finite radial dimension of cover is taken into account it will lead to widening of water density interval for which the limiting subcriticality is ensured. Corresponding calculations (if necessary) should be performed during future studies after definition of MOX fuel treatment technology. 


\section{3 LTAs introduction in VVER-1000 and transportation problems}

The presented calculations can be considered as conservative for the case of 3 MOX LTAs transportation. So it seems that no nuclear safety problems will appear for transportation of 3 fresh MOX LTAs at VVER-1000 NPP if the conservative case meets safety limitations. 


\section{Conclusion}

The performed preliminary analysis of nuclear safety during transport and storage of MOX fuel shows that:

- Limiting subcriticality is ensured in an infinite grid of package sets for UOX and MOX FAs under normal operation and design accidents. For transport package sets placed in not more than 4 decks with no limitations for width the authorized value of subcriticality is ensured also in few probable accidental situation with adverse water density distribution.

- Cooling pools equipped with decks of non-compact storage of the fuel and covers for fresh FAs, according to conservative calculations, ensure the limiting subcriticality in the water density interval of $0.5-1.0 \mathrm{~g} / \mathrm{cm}^{3}$ and for the densities about 0 .

- Cooling pools equipped with decks of close (compact) storage of the fuel, based on the hexagonal borated steel, ensure the limiting subcriticality in all considered normal operation and accidental conditions.

- 3 MOX LTAs will not cause any nuclear safety problems in the means of transportation and storage. 


\section{References}

1. Pavlovichev A.M. “Mission fuel physics design. Equilibrium VVER-1000 Core Loading with 1/3 MOX fuel”. Draft, RRC KI. Moscow, 2000.

2. Safety rules for nuclear fuel storage and transport at the nuclear engineering object. PNAEG-14-029-91, Moscow, Energoatomizdat, 1992.

3. Gomin E.A., Gurevich M.I., Maiorov L.V., Marin S.V. Annotation of the MCURFFI code. VANT, Reactor Physic Series, 1995, vol.3, pp.48-53. 


\section{Part 2}

\section{Radiation Safety}

Executed by

A.G. Khohlov

G.N. Khohlov A.G. Tsikounov 


\begin{abstract}
Three pilot FAs with MOX fuel based on weapons-grade plutonium are assumed to be positioned in reactor core of Balakovo NPP for research on features of MOX fuel using in VVER-1000 reactors.

Particular attention should be given to radiation situation when MOX FAs handling including investigation for feasibility of using existing equipment and facilities of transport-technological path.

Some radiation characteristics of uranium and MOX fuel for VVER-1000 reactor are considered in the report. Calculation model of inplant jacket for transportation and temporary storage of fresh FAs is given. Radiation situation for different variants of jacket loading with uranium FAs and pilot FAs with MOX fuel is estimated by calculational approach.
\end{abstract}




\section{CONTENT}

INTRODUCTION........................................................................................ 4

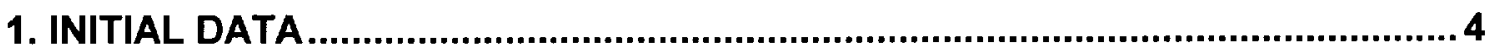

2. RADIATION SOURCES IN FRESH FUEL ASSEMBLIES.................................5

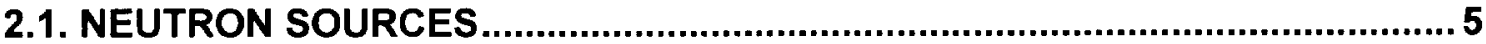

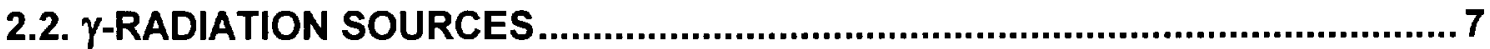

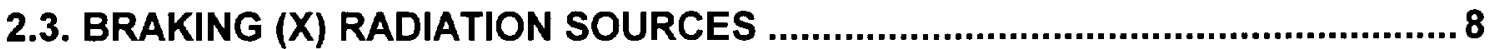

3. CALCULATION METHODS AND SOFTWARE............................................ 9

4. CALCULATION ESTIMATIONS OF EQUIVALENT DOSE RATES ................... 10

4.1. UNSHIELDED FA ................................................................................. 10

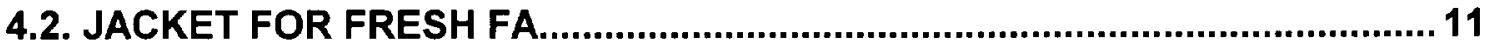

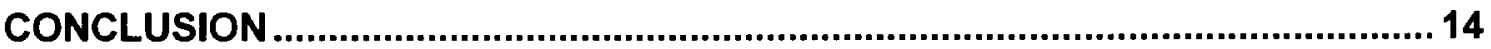

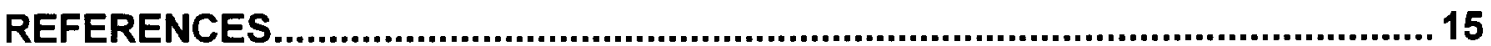




\section{INTRODUCTION}

In report $/ 1 /$ calculation estimations were performed for dose rate levels when operating with fresh fuel in different stages of FA passing along the transport-technological path.

Major purpose of this kind studies - to estimate on the basis of two types fuel (uranium and mixed) comparison the necessity for changes in design of transport packing sets, shielding of transport technological path etc. in the case of MOX fuel utilization.

Dose rate levels were considered caused by neutron and gamma-radiation in the following cases:

- unshielded FA;

- FA in a sealed packing set;

- stacks of packing sets in fresh fuel storage;

- damaged FA in boxes;

- FA in jackets for transportation and storage of fresh FA;

- fresh FA in a boom of reloading machine.

In present paper the radiation situation during transportation and storing of three pilot MOX FAs in jacket with 18 positions that is used in Balakovo NPP as a transport cask for shipping and temporary storage of FAs with fresh uranium fuel has been estimated. Different variants of jacket loading have been considered: both with MOX FAs solely and together with uranium FAs.

\section{INITIAL DATA}

Two types of fuel are considered: $\mathrm{UO}_{2}$ with $4.4 \%$ enrichment by ${ }^{235} \mathrm{U}$ and $\left(\mathrm{UO}_{2}+\mathrm{PuO}_{2}\right)$ on the basis of weapons-grade plutonium with $4.2 \%$ enrichment by plutonium.

The following plutonium isotope composition was adopted:

\begin{tabular}{rccccc}
\hline \hline${ }^{238} \mathrm{Pu}$ & ${ }^{239} \mathrm{Pu}$ & ${ }^{240} \mathrm{Pu}$ & ${ }^{241} \mathrm{Pu}$ & ${ }^{242} \mathrm{Pu}$ & ${ }^{241} \mathrm{Am}$ \\
0.02 & 93.94 & 5.81 & 0.18 & 0.03 & 0.02 \\
\hline \hline
\end{tabular}

${ }^{241} \mathrm{Am}$ content in plutonium corresponds to $\sim 2$ year stand after plutonium separation.

The same standing time was adopted for uranium and MOX fuel as well.

Tables 1 and 2 give the parameters of FA active part and loaded fresh fuel used in subsequent calculations. 
Table 1

FA active part parameters

\begin{tabular}{|lc||}
\hline Length, cm & 353 \\
"Flat-to-flat" dimension, cm & 23.4 \\
Fuel rod number & 312 \\
Cladding material & circonium \\
Outer cladding diameter, cm & 0.91 \\
Clad thickness, cm & 0.069 \\
Pellet diameter, cm & 0.753 \\
Central hole diameter, cm & 0.15 \\
$\mathrm{UO}_{2}$ density, $\mathrm{g} / \mathrm{cm}^{3}$ & 10.5 \\
$\mathrm{UO}_{2}$ mass, g & $4.95 \mathrm{E}+05$ \\
\hline
\end{tabular}

Table 2

Actinide composition in fresh $F A$

\begin{tabular}{||l|l|l|}
\hline Fuel type & $\mathrm{UO}_{2}$ & MOX \\
\hline \hline${ }^{234} \mathrm{U}$ & $0.04 \%$ & $0.001 \%$ \\
${ }^{235} \mathrm{U}$ & $4.4 \%$ & $0.2 \%$ \\
${ }^{236} \mathrm{U}$ & & \\
${ }^{238} \mathrm{U}$ & $95.6 \%$ & $95.6 \%$ \\
${ }^{237} \mathrm{~Np}+{ }^{233} \mathrm{~Pa}$ & & \\
${ }^{238} \mathrm{Pu}$ & & $0.0008 \%$ \\
${ }^{239} \mathrm{Pu}$ & & $3.9 \%$ \\
${ }^{240} \mathrm{Pu}$ & $0.24 \%$ \\
${ }^{241} \mathrm{Pu}+{ }^{237} \mathrm{U}$ & & $0.0076 \%$ \\
${ }^{242} \mathrm{Pu}$ & & $0.0013 \%$ \\
${ }^{241} \mathrm{Am}$ & & $0.00084 \%$ \\
\hline
\end{tabular}

\section{RADIATION SOURCES IN FRESH FUEL ASSEMBLIES}

\subsection{Neutron Sources}

Calculation of neutron and $\gamma$-sources was carried out using CARE code $/ 2 /$, allowing the calculation of isotope kinetics for fuel element nuclei at both radioactive decay and neutron interactions.

Neutron source spectra were calculated in 26-group presentation of ABBN constant system $/ 3 /$, energy division of which is presented in Table 3 . This table presents also corresponding division of the energy scale for $\gamma$-quanta. In subsequent calculations of $(n, \gamma)$-problems capture $\gamma$-radiation is described in 15-group approximation as opposed to problems with independent $\gamma$-sources (see section 2.2). 
Table 3

Energy division of ABBN constant system

\begin{tabular}{||c|cc|c|c||}
\hline \multirow{2}{*}{$\begin{array}{c}\text { Group } \\
\text { № }\end{array}$} & \multicolumn{2}{|c|}{ Neutrons } & \multicolumn{2}{c|}{$\gamma$-quanta } \\
\cline { 2 - 5 } & $\mathrm{E}_{\min }$ & $\mathrm{E}_{\max }$ & $\mathrm{E}_{\min }, \mathrm{MeV}$ & $\mathrm{E}_{\max }, \mathrm{MeV}$ \\
\hline \hline 1 & $6.5 \mathrm{MeV}$ & $10.5 \mathrm{MeV}$ & 9.0 & 11.0 \\
2 & 4.0 & 6.5 & 7.0 & 9.0 \\
3 & 2.5 & 4.0 & 5.5 & 7.0 \\
4 & 1.4 & 2.5 & 4.5 & 5.5 \\
5 & 0.8 & 1.4 & 3.5 & 4.5 \\
6 & 0.4 & 0.8 & 2.5 & 3.5 \\
7 & 0.2 & 0.4 & 1.75 & 2.5 \\
8 & $100.0 \mathrm{keV}$ & 0.2 & 1.25 & 1.75 \\
9 & 46.5 & $100.0 \mathrm{keV}$ & 0.75 & 1.25 \\
10 & 21.5 & 46.5 & 0.35 & 0.75 \\
11 & 10 & 21.5 & 0.15 & 0.35 \\
12 & 4.65 & 10 & 0.08 & 0.15 \\
13 & 2.15 & 4.65 & 0.04 & 0.08 \\
14 & 1.0 & 2.15 & 0.02 & 0.04 \\
15 & $465.0 \mathrm{eV}$ & 1.0 & 0.015 & 0.02 \\
16 & 215.0 & $465.0 \mathrm{eV}$ & & \\
17 & 100.0 & 215.0 & & \\
18 & 46.5 & 100.0 & & \\
19 & 21.5 & 46.5 & & \\
20 & 10.0 & 21.5 & & \\
21 & 4.65 & 10.0 & & \\
22 & 2.15 & 4.65 & & \\
23 & 1.0 & 2.15 & & \\
24 & 0.465 & 1.0 & & \\
25 & 0.215 & 0.465 & & \\
26 & \multicolumn{5}{|c}{0.0253} & & \\
\hline \multicolumn{5}{|c|}{} \\
\hline
\end{tabular}

When calculating neutron source, neutrons were taken into account forming at spontaneous actinide fission and in $(\alpha, n)$-reaction with oxygen. Table 4 presents calculation results for spectrum and intensity of neutron sources in fresh uranium and MOX fuel. Radiation spectral parameters are given in relative units (normalized to 1).

Major contribution to a full intensity of neutron source in uranium fuel is introduced by ${ }^{238} \mathrm{U}(\sim 91 \%)$ and ${ }^{234} \mathrm{U}(\sim 8.6 \%)$, in $\mathrm{MOX}$ fuel $-{ }^{240} \mathrm{Pu}(\sim 62 \%)$, ${ }^{239} \mathrm{Pu}(\sim 34 \%)$ and ${ }^{238} \mathrm{Pu}(\sim 3 \%)$. 
Table 4

Neutron radiation spectral composition, rel. units

\begin{tabular}{|c|c|c|c|c|c|c|}
\hline \multirow{2}{*}{$\begin{array}{c}\text { Group } \\
\text { № }\end{array}$} & \multicolumn{3}{|c|}{$\mathrm{UO}_{2}$} & \multicolumn{3}{|c|}{ MOX } \\
\hline & SF & $(\alpha, n)$ & $\mathrm{SF}+(\alpha, \mathrm{n})$ & SF & $(\alpha, n)$ & $\mathrm{SF}+(\alpha, n)$ \\
\hline 1 & $1.38 \mathrm{E}-02$ & $\overline{0.00 \mathrm{E}+00}$ & $1.25 \mathrm{E}-02$ & $1.49 \mathrm{E}-02$ & $0.00 \mathrm{E}+00$ & $8.22 \mathrm{E}-03$ \\
\hline 2 & $7.88 \mathrm{E}-02$ & $0.00 \mathrm{E}+00$ & $7.14 \mathrm{E}-02$ & 8.23E-02 & $3.40 \mathrm{E}-04$ & $4.56 \mathrm{E}-02$ \\
\hline 3 & $1.71 \mathrm{E}-01$ & $8.22 \mathrm{E}-02$ & $1.63 \mathrm{E}-01$ & $1.75 \mathrm{E}-01$ & $8.89 \mathrm{E}-02$ & $1.36 \mathrm{E}-01$ \\
\hline 4 & $2.66 \mathrm{E}-01$ & $2.28 \mathrm{E}-01$ & $2.63 \mathrm{E}-01$ & $2.67 \mathrm{E}-01$ & $2.17 \mathrm{E}-01$ & $2.45 \mathrm{E}-01$ \\
\hline 5 & $2.09 \mathrm{E}-01$ & $9.74 \mathrm{E}-02$ & $1.99 \mathrm{E}-01$ & $2.07 \mathrm{E}-01$ & $9.90 \mathrm{E}-02$ & $1.59 \mathrm{E}-01$ \\
\hline 6 & $1.51 \mathrm{E}-01$ & $1.20 \mathrm{E}-01$ & $1.48 \mathrm{E}-01$ & $1.48 \mathrm{E}-01$ & $1.24 \mathrm{E}-01$ & $1.37 \mathrm{E}-01$ \\
\hline 7 & $6.74 \mathrm{E}-02$ & $1.23 \mathrm{E}-01$ & $7.26 \mathrm{E}-02$ & $6.53 \mathrm{E}-02$ & $1.24 \mathrm{E}-01$ & $9.18 \mathrm{E}-02$ \\
\hline 8 & $2.67 \mathrm{E}-02$ & $1.07 \mathrm{E}-01$ & $3.43 \mathrm{E}-02$ & $2.59 \mathrm{E}-02$ & $1.08 \mathrm{E}-01$ & $6.25 \mathrm{E}-02$ \\
\hline 9 & $1.06 \mathrm{E}-02$ & $1.30 \mathrm{E}-01$ & $2.18 \mathrm{E}-02$ & $1.03 \mathrm{E}-02$ & $1.28 \mathrm{E}-01$ & $6.30 \mathrm{E}-02$ \\
\hline 10 & $3.46 \mathrm{E}-03$ & $6.02 \mathrm{E}-02$ & $8.78 \mathrm{E}-03$ & $3.34 \mathrm{E}-03$ & $5.94 \mathrm{E}-02$ & $2.85 \mathrm{E}-02$ \\
\hline 11 & $1.11 \mathrm{E}-03$ & $2.78 \mathrm{E}-02$ & $3.61 \mathrm{E}-03$ & $1.07 \mathrm{E}-03$ & $2.74 \mathrm{E}-02$ & $1.29 \mathrm{E}-02$ \\
\hline 12 & $3.53 \mathrm{E}-04$ & $1.30 \mathrm{E}-02$ & $1.53 \mathrm{E}-03$ & $3.41 \mathrm{E}-04$ & $1.28 \mathrm{E}-02$ & $5.92 \mathrm{E}-03$ \\
\hline 13 & $1.12 \mathrm{E}-04$ & $6.02 \mathrm{E}-03$ & $6.65 \mathrm{E}-04$ & $1.08 \mathrm{E}-04$ & $5.94 \mathrm{E}-03$ & $2.72 \mathrm{E}-03$ \\
\hline 14 & $3.55 \mathrm{E}-05$ & $2.78 \mathrm{E}-03$ & $2.93 \mathrm{E}-04$ & $3.42 \mathrm{E}-05$ & $2.74 \mathrm{E}-03$ & $1.25 \mathrm{E}-03$ \\
\hline 15 & $1.12 \mathrm{E}-05$ & $1.30 \mathrm{E}-03$ & $1.32 \mathrm{E}-04$ & $1.08 \mathrm{E}-05$ & $1.28 \mathrm{E}-03$ & $5.79 \mathrm{E}-04$ \\
\hline 16 & $3.55 \mathrm{E}-06$ & $6.02 \mathrm{E}-04$ & $5.96 \mathrm{E}-05$ & $3.43 \mathrm{E}-06$ & $5.94 \mathrm{E}-04$ & $2.68 \mathrm{E}-04$ \\
\hline 17 & $1.12 \mathrm{E}-06$ & $2.78 \mathrm{E}-04$ & 2.71 & $1.08 \mathrm{E}-06$ & $2.74 \mathrm{E}-04$ & $1.24 \mathrm{E}-04$ \\
\hline 18 & $3.55 \mathrm{E}-07$ & $1.30 \mathrm{E}-04$ & 1.25 & $3.43 \mathrm{E}-07$ & $1.28 \mathrm{E}-04$ & $5.75 \mathrm{E}-05$ \\
\hline 19 & $1.12 \mathrm{E}-07$ & $6.02 \mathrm{E}-05$ & $5.74 \mathrm{E}-06$ & $1.08 \mathrm{E}-07$ & $5.94 \mathrm{E}-05$ & $2.67 \mathrm{E}-05$ \\
\hline 20 & $3.55 \mathrm{E}-08$ & $2.78 \mathrm{E}-05$ & 2.64 & $3.43 \mathrm{E}-08$ & $2.74 \mathrm{E}-05$ & $1.23 \mathrm{E}-05$ \\
\hline 21 & $1.12 \mathrm{E}-08$ & $1.30 \mathrm{E}-05$ & $1.22 \mathrm{E}-06$ & $1.08 \mathrm{E}-08$ & $1.28 \mathrm{E}-05$ & $5.73 E-06$ \\
\hline 22 & $3.55 \mathrm{E}-09$ & $6.02 \mathrm{E}-06$ & $5.67 \mathrm{E}-07$ & $3.43 \mathrm{E}-09$ & $5.94 \mathrm{E}-06$ & $2.66 \mathrm{E}-06$ \\
\hline 23 & $1.12 \mathrm{E}-09$ & $2.78 \mathrm{E}-06$ & $2.61 \mathrm{E}-07$ & $1.08 \mathrm{E}-09$ & $2.74 \mathrm{E}-06$ & $1.23 \mathrm{E}-06$ \\
\hline 24 & $3.55 \mathrm{E}-10$ & $1.30 \mathrm{E}-06$ & $1.22 \mathrm{E}-07$ & $3.43 \mathrm{E}-10$ & $1.28 \mathrm{E}-06$ & $5.73 \mathrm{E}-07$ \\
\hline 25 & $1.12 \mathrm{E}-10$ & $6.02 \mathrm{E}-07$ & $5.65 \mathrm{E}-08$ & $1.08 \mathrm{E}-10$ & $5.94 \mathrm{E}-07$ & $2.66 \mathrm{E}-07$ \\
\hline 26 & $4.98 \mathrm{E}-11$ & $5.20 \mathrm{E}-07$ & $4.87 \mathrm{E}-08$ & $4.81 \mathrm{E}-11$ & $5.13 \mathrm{E}-07$ & $2.30 \mathrm{E}-07$ \\
\hline $\mathrm{n} / \mathrm{s} \cdot \mathrm{FA}$ & $5.32 \mathrm{E}+03$ & $5.49 \mathrm{E}+02$ & $5.87 \mathrm{E}+03$ & $1.13 E+06$ & $9.15 \mathrm{E}+05$ & $2.04 E+06$ \\
\hline
\end{tabular}

\section{2. $\gamma$-radiation Sources}

Preliminary calculations connected with determination of $\gamma$-dose rates on FA surface and at some distance from it have shown that the use of 15-group ABBN constant system for fresh fuel is not sufficient due to rough description of $\gamma$-quantum source spectrum in the energy range up to $\sim 600 \mathrm{keV}$. Hence in calculations a 25 -group constant system obtained from VITAMIN-C 36-group constant system was used.

Table 5 presents an energy division and spectral characteristics for the both fuel types.

Full intensity of $\gamma$-source in uranium fuel is formed due to ${ }^{234} U(\sim 47 \%)$, ${ }^{235} \mathrm{U}(\sim 19 \%),{ }^{231} \mathrm{Th} \quad(\sim 16 \%),{ }^{234} \mathrm{Th} \quad(\sim 11 \%),{ }^{238} \mathrm{U} \quad(\sim 5 \%)$ and ${ }^{234 \mathrm{~m}} \mathrm{~Pa} \quad(\sim 1 \%)$. 
${ }^{239} \mathrm{Pu}(\sim 42 \%),{ }^{240} \mathrm{Pu}(\sim 24 \%),{ }^{238} \mathrm{Pu}(\sim 6.4 \%)$ and ${ }^{241} \mathrm{Am}(\sim 3 \%)$ contributing mainly to intensity in MOX fuel.

Table 5

$\gamma$-radiation spectral composition, rel. units

\begin{tabular}{|c|c|c|c|c||}
\hline Group № & $\mathrm{E}_{\min }, \mathrm{MeV}$ & $\mathrm{E}_{\max }, \mathrm{MeV}$ & $\mathrm{UO}_{2}$ & $\mathrm{MOX}$ \\
\hline \hline 1 & 3.5 & 14.0 & $0.00 \mathrm{E}+00$ & $0.00 \mathrm{E}+00$ \\
2 & 3.0 & 3.5 & $0.00 \mathrm{E}+00$ & $0.00 \mathrm{E}+00$ \\
3 & 2.5 & 3.0 & $0.00 \mathrm{E}+00$ & $1.32 \mathrm{E}-19$ \\
4 & 2.00 & 2.5 & $0.00 \mathrm{E}+00$ & $0.00 \mathrm{E}+00$ \\
5 & 1.66 & 2.00 & $3.38 \mathrm{E}-04$ & $7.99 \mathrm{E}-07$ \\
6 & 1.50 & 1.66 & $1.32 \mathrm{E}-04$ & $3.12 \mathrm{E}-07$ \\
7 & 1.33 & 1.50 & $9.77 \mathrm{E}-05$ & $2.31 \mathrm{E}-07$ \\
8 & 1.00 & 1.33 & $2.91 \mathrm{E}-03$ & $6.87 \mathrm{E}-06$ \\
9 & 0.8 & 1.00 & $9.90 \mathrm{E}-04$ & $2.34 \mathrm{E}-06$ \\
10 & 0.7 & 0.8 & $1.95 \mathrm{E}-03$ & $4.60 \mathrm{E}-06$ \\
11 & 0.6 & 0.7 & $1.49 \mathrm{E}-04$ & $3.52 \mathrm{E}-07$ \\
12 & 0.512 & 0.6 & $1.52 \mathrm{E}-04$ & $3.59 \mathrm{E}-07$ \\
13 & 0.51 & 0.512 & $0.00 \mathrm{E}+00$ & $3.00 \mathrm{E}-20$ \\
14 & 0.5 & 0.51 & $2.18 \mathrm{E}-05$ & $1.77 \mathrm{E}-05$ \\
15 & 0.4 & 0.5 & $0.00 \mathrm{E}+00$ & $1.44 \mathrm{E}-04$ \\
16 & 0.3 & 0.4 & $1.03 \mathrm{E}-04$ & $3.76 \mathrm{E}-04$ \\
17 & 0.2 & 0.3 & $8.27 \mathrm{E}-03$ & $4.63 \mathrm{E}-05$ \\
18 & 0.15 & 0.2 & $1.01 \mathrm{E}-01$ & $1.22 \mathrm{E}-05$ \\
19 & 0.1 & 0.15 & $3.06 \mathrm{E}-02$ & $9.89 \mathrm{E}-04$ \\
20 & 0.075 & 0.1 & $6.57 \mathrm{E}-02$ & $1.23 \mathrm{E}-03$ \\
21 & 0.06 & 0.075 & $2.01 \mathrm{E}-02$ & $4.64 \mathrm{E}-05$ \\
22 & 0.045 & 0.06 & $6.41 \mathrm{E}-03$ & $1.06 \mathrm{E}-01$ \\
23 & 0.03 & 0.045 & $0.00 \mathrm{E}+00$ & $1.12 \mathrm{E}-03$ \\
24 & 0.02 & 0.03 & $2.44 \mathrm{E}-02$ & $8.86 \mathrm{E}-02$ \\
25 & 0.01 & 0.02 & $7.37 \mathrm{E}-01$ & $8.01 \mathrm{E}-01$ \\
\hline Full intensity, quantum/s $\mathrm{FA}$ & $8.78 \mathrm{E}+09$ & $4.07 \mathrm{E}+12$ \\
\hline \multicolumn{5}{|r}{} \\
\hline
\end{tabular}

\subsection{Braking (X) Radiation Sources}

An availability of braking radiation is a characteristic feature of fuel containing ${ }^{238} \mathrm{U}$ due to short-lived daughter product of its decay $-{ }^{234 \mathrm{~m}} \mathrm{~Pa}$. Maximum energy of ${ }^{234 \mathrm{~m}} \mathrm{~Pa} \beta$-particles is $\sim 2.3 \mathrm{MeV}$, therefore, $\mathrm{X}$-radiation accompanying $\beta$-particle braking in the medium is much more hard, as compared with other $\beta$-emitters. Table 6 presents in 25-group presentation the calculated braking radiation spectra for uranium and MOX fuel.

A source intensity in uranium fuel is defined by ${ }^{234 \mathrm{~m}} \mathrm{~Pa}(\sim 98 \%)$, and in MOX fuel - by ${ }^{241} \mathrm{Pu}(\sim 96 \%)$, whereas ${ }^{234 \mathrm{~m}} \mathrm{~Pa}$ fraction is $\sim 4.6 \%$ only, however, as is seen from the table, the whole plutonium X-radiation is concentrated in soft spectrum part, and therefore is practically completely absorbed in FA structure material. The X-rays 
radiation intensity defined by ${ }^{234 \mathrm{~m}} \mathrm{~Pa}$, is determined only by ${ }^{238} \mathrm{U}$ isotope content in fuel and thus creates the same dose rate on FA surface as in the case of uranium fuel.

\section{Table 6}

Braking radiation spectral composition, rel. units

\begin{tabular}{|c|c|c|}
\hline Group № & $\mathrm{UO}_{2}$ & MOX \\
\hline \hline $1 \ldots 4$ & $0.00 \mathrm{E}+00$ & $0.00 \mathrm{E}+00$ \\
5 & $1.11 \mathrm{E}-04$ & $4.85 \mathrm{E}-06$ \\
6 & $2.72 \mathrm{E}-04$ & $1.18 \mathrm{E}-05$ \\
7 & $7.20 \mathrm{E}-04$ & $3.14 \mathrm{E}-05$ \\
8 & $4.58 \mathrm{E}-03$ & $2.00 \mathrm{E}-04$ \\
9 & $8.11 \mathrm{E}-03$ & $3.54 \mathrm{E}-04$ \\
10 & $7.29 \mathrm{E}-03$ & $3.18 \mathrm{E}-04$ \\
11 & $1.11 \mathrm{E}-02$ & $4.82 \mathrm{E}-04$ \\
12 & $1.41 \mathrm{E}-02$ & $6.15 \mathrm{E}-04$ \\
13 & $3.96 \mathrm{E}-04$ & $1.73 \mathrm{E}-05$ \\
14 & $2.03 \mathrm{E}-03$ & $8.86 \mathrm{E}-05$ \\
15 & $2.60 \mathrm{E}-02$ & $1.13 \mathrm{E}-03$ \\
16 & $4.10 \mathrm{E}-02$ & $1.79 \mathrm{E}-03$ \\
17 & $7.43 \mathrm{E}-02$ & $3.24 \mathrm{E}-03$ \\
18 & $6.26 \mathrm{E}-02$ & $2.73 \mathrm{E}-03$ \\
19 & $9.68 \mathrm{E}-02$ & $4.20 \mathrm{E}-03$ \\
20 & $7.43 \mathrm{E}-02$ & $3.22 \mathrm{E}-03$ \\
21 & $6.02 \mathrm{E}-02$ & $2.60 \mathrm{E}-03$ \\
22 & $7.97 \mathrm{E}-02$ & $3.44 \mathrm{E}-03$ \\
23 & $1.15 \mathrm{E}-01$ & $4.97 \mathrm{E}-03$ \\
24 & $1.18 \mathrm{E}-01$ & $5.10 \mathrm{E}-03$ \\
25 & $2.03 \mathrm{E}-01$ & $9.65 \mathrm{E}-01$ \\
\hline quantum/sFA & $1.32 \mathrm{E}+09$ & $3.32 \mathrm{E}+10$ \\
\hline
\end{tabular}

\section{Calculation Methods and Software}

Radiation field calculations were performed in $\mathrm{S}_{8} \mathrm{P}_{1}$-approximation using DOT-3.5 code $14 /$.

When solving ( $\mathrm{n}, \gamma)$-problems the ABBN-93 constant system $/ 3 /$ was used and for problems with $\gamma$-sources VITAMIN-C was used. Macroscopic cross-sections for material mixtures were prepared with the use of CONSYST complex $/ 3 /$ in the case of ABBN constant system application, in the case of VITAMIN-C - GIP code. in Table 7.

"Dose coefficients" /5/ used in equivalent dose rate calculations are presented 
Table 7

Dose coefficients, $(\mu \mathrm{k} \cdot \mathrm{Sv} / \mathrm{h}) /\left(1 / \mathrm{s}^{\cdot} \mathrm{cm}^{2}\right)$

\begin{tabular}{|c|c|c|c||}
\hline \multirow{2}{*}{$\begin{array}{c}\text { Group } \\
\text { № }\end{array}$} & \multirow{2}{*}{ Neutrons } & \multicolumn{2}{|c|}{$\gamma$-quanta } \\
\cline { 3 - 4 } & & ABBN & VITAMIN-C \\
\hline \hline 1 & $2.01 \mathrm{E}+00$ & $9.47 \mathrm{E}-02$ & $8.60 \mathrm{E}-02$ \\
2 & $1.90 \mathrm{E}+00$ & $7.97 \mathrm{E}-02$ & $4.41 \mathrm{E}-02$ \\
3 & $1.72 \mathrm{E}+00$ & $6.66 \mathrm{E}-02$ & $3.96 \mathrm{E}-02$ \\
4 & $1.57 \mathrm{E}+00$ & $5.72 \mathrm{E}-02$ & $3.47 \mathrm{E}-02$ \\
5 & $1.55 \mathrm{E}+00$ & $4.96 \mathrm{E}-02$ & $3.02 \mathrm{E}-02$ \\
6 & $1.47 \mathrm{E}+00$ & $4.13 \mathrm{E}-02$ & $2.73 \mathrm{E}-02$ \\
7 & $1.32 \mathrm{E}+00$ & $3.31 \mathrm{E}-02$ & $2.53 \mathrm{E}-02$ \\
8 & $1.01 \mathrm{E}+00$ & $2.61 \mathrm{E}-02$ & $2.20 \mathrm{E}-02$ \\
9 & $6.16 \mathrm{E}-01$ & $1.95 \mathrm{E}-02$ & $1.83 \mathrm{E}-02$ \\
10 & $3.75 \mathrm{E}-01$ & $1.24 \mathrm{E}-02$ & $1.60 \mathrm{E}-02$ \\
11 & $2.17 \mathrm{E}-01$ & $6.14 \mathrm{E}-03$ & $1.44 \mathrm{E}-02$ \\
12 & $1.02 \mathrm{E}-01$ & $3.15 \mathrm{E}-03$ & $1.28 \mathrm{E}-02$ \\
13 & $6.05 \mathrm{E}-02$ & $2.94 \mathrm{E}-03$ & $1.19 \mathrm{E}-02$ \\
14 & $5.82 \mathrm{E}-02$ & $9.69 \mathrm{E}-03$ & $1.18 \mathrm{E}-02$ \\
15 & $6.35 \mathrm{E}-02$ & $3.12 \mathrm{E}-02$ & $1.08 \mathrm{E}-02$ \\
16 & $7.02 \mathrm{E}-02$ & & $8.75 \mathrm{E}-03$ \\
17 & $7.33 \mathrm{E}-02$ & & $6.31 \mathrm{E}-03$ \\
18 & $7.47 \mathrm{E}-02$ & & $4.40 \mathrm{E}-03$ \\
19 & $7.54 \mathrm{E}-02$ & & $3.31 \mathrm{E}-03$ \\
20 & $7.56 \mathrm{E}-02$ & & $2.73 \mathrm{E}-03$ \\
21 & $7.56 \mathrm{E}-02$ & & $2.64 \mathrm{E}-03$ \\
22 & $7.56 \mathrm{E}-02$ & & $2.97 \mathrm{E}-03$ \\
23 & $7.56 \mathrm{E}-02$ & & $4.73 \mathrm{E}-03$ \\
24 & $7.56 \mathrm{E}-02$ & & $1.43 \mathrm{E}-02$ \\
25 & $7.56 \mathrm{E}-02$ & & $3.12 \mathrm{E}-02$ \\
26 & $6.38 \mathrm{E}-02$ & & \\
27 & $4.65 \mathrm{E}-02$ & & \\
28 & $3.74 \mathrm{E}-02$ & & \\
\hline
\end{tabular}

\section{Calculation Estimations of Equivalent Dose Rates}

\subsection{Unshielded FA}

Dose rate calculation for unshielded FA was performed previously (see Ref. /1/). Here Table 8 gives only the results.

In this table:

$D_{n}$ - the dose rate, defined by the neutron source (spontaneous actinide fission $+(\alpha, n)$-reaction on oxygen);

$D_{n, \gamma}, D_{\gamma}, D_{\gamma(\beta)}$ - dose rates due to capture irradiation, actinide $\gamma$ radiation, and braking $(\mathrm{X})$ radiation, correspondingly;

$\Sigma_{\gamma}$ - the dose rate from all components of $\mathrm{X}$ and $\gamma$-radiation;

$\mathrm{D}_{\Sigma}$ - the equivalent dose full rate value. 
Table 8

Equivalent dose rate from unshielded FA with fresh fuel, $\mu \mathrm{kSv} / \mathrm{h}$

\begin{tabular}{||c|c|c|c|c|c|c||}
\hline \hline $\begin{array}{c}\text { Distance from FA } \\
\text { surface, cm }\end{array}$ & $\mathrm{D}_{\mathrm{n}}$ & $\mathrm{D}_{\mathrm{n}, \gamma}$ & $\mathrm{D}_{\gamma}$ & $\mathrm{D}_{\gamma(\beta)}$ & $\Sigma_{\gamma}$ & $\mathrm{D}_{\Sigma}$ \\
\hline \hline \multicolumn{7}{|c||}{$\mathrm{UO}_{2}$} \\
\hline 0 & $4.10-1$ & $7.49-4$ & $3.30+1$ & $2.65+1$ & $5.95+1$ & $\mathbf{5 . 9 9 + 1}$ \\
50 & $1.78-1$ & $3.22-4$ & $1.40+1$ & $1.11+1$ & $2.51+1$ & $\mathbf{2 . 5 3 + 1}$ \\
100 & $5.76-2$ & $1.05-4$ & $4.54+0$ & $3.57+0$ & $\mathbf{8 . 1 1 + 0}$ & $\mathbf{8 . 2 7}+\mathbf{0}$ \\
200 & $2.92-2$ & $5.33-5$ & $2.32+0$ & $1.83+0$ & $4.15+0$ & $\mathbf{4 . 1 8 + 0}$ \\
\hline 0 & $1.11-2$ & $2.06-5$ & $8.82-1$ & $6.91-1$ & $1.57+0$ & $\mathbf{1 . 5 8 + 0}$ \\
\hline 0 & $1.26+2$ & $2.17-1$ & $2.30+2$ & $2.90+1$ & $2.59+2$ & $\mathbf{3 . 8 5 + 2}$ \\
50 & $5.47+1$ & $9.32-2$ & $9.72+1$ & $1.21+1$ & $1.09+2$ & $\mathbf{1 . 6 4 + 2}$ \\
100 & $1.77+1$ & $3.03-2$ & $3.15+1$ & $3.92+0$ & $3.55+1$ & $\mathbf{5 . 3 2 + 1}$ \\
200 & $9.00+0$ & $1.54-2$ & $1.62+1$ & $2.00+0$ & $1.82+1$ & $\mathbf{2 . 7 2 + 1}$ \\
\hline 0
\end{tabular}

\subsection{Jacket for Fresh FA}

Fig. 1 shows a jacket design for FA transportation to reactor hall and their temporary storing in the fresh fuel storage.

A calculation model in two-dimensional $(\mathrm{R}, \mathrm{Z})$-geometry is presented in Fig. 2.

Three variants of jacket using were considered:

A. Three MOX FAs are uniformly distributed in inner row (outer row is free).

B. Three MOX FAs are loaded in inner row and 12 FAs with $\mathrm{UO}_{2}$ fuel are in outer row.

C. Three MOX FAs and three FAs with $\mathrm{UO}_{2}$ fuel are positioned in inner row, 12 FAs with $\mathrm{UO}_{2}$ fuel are in outer row.

As is seen from Figure 2, FA distribution in jacket is simulated by two layers in which FA materials are homogeneously stirred according to variants of FA loading. Table 9 presents radial distributions of equivalent dose rate at distance up to $2 \mathrm{~m}$ from jacket surface for all considered variants. 

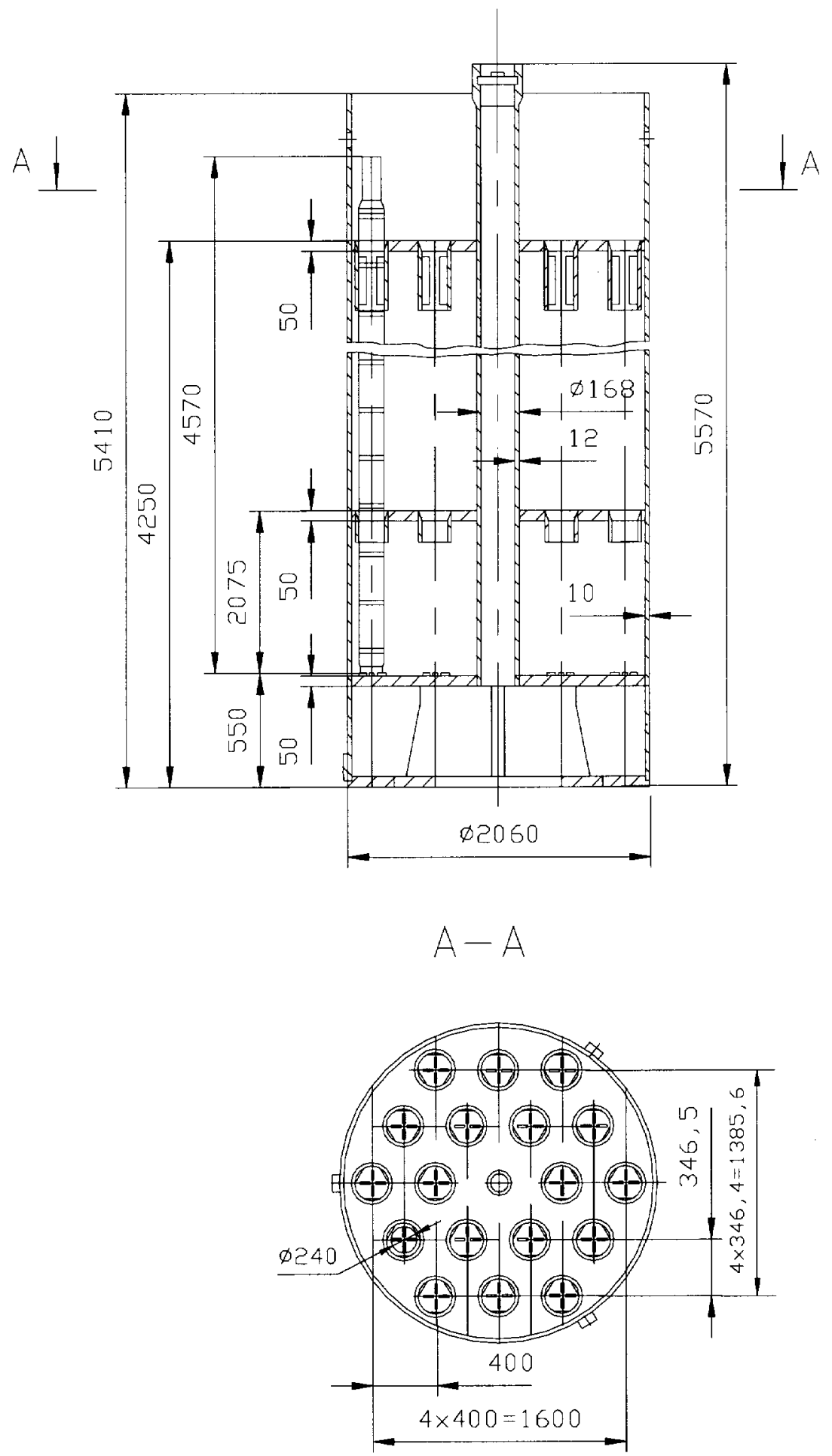

Fig. 1. A jacket for fresh FA 


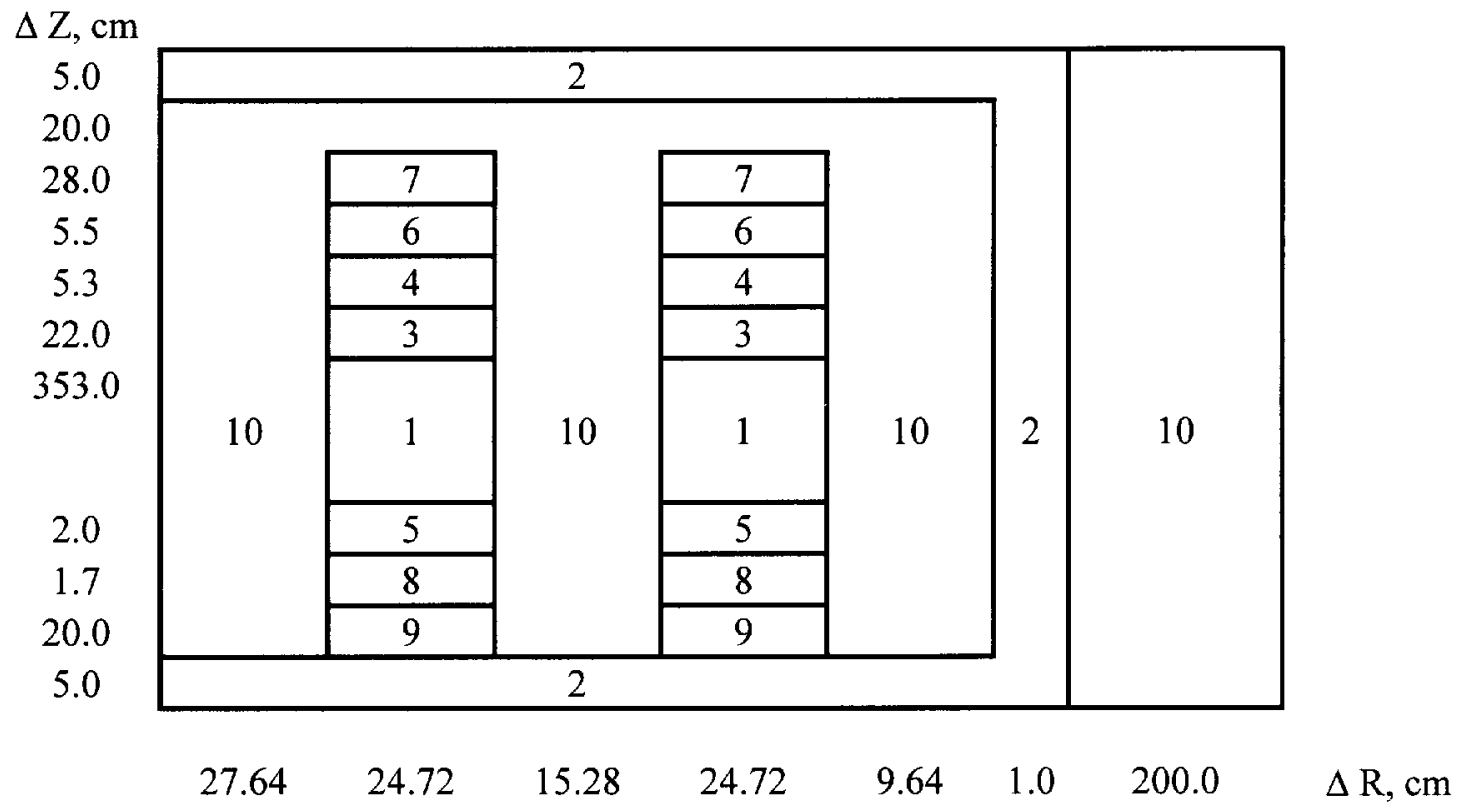

Notations:

1 - Core

2 - Jacket steel

4 - Fuel pin fillers

7 - FA head

3 - Compensation volume

5 - Fuel pin end

8 - Lower grid

9 - FA end component

10 - Air

Fig. 2. Calculation (R,Z)-model of jacket for fresh FA

Table 9

Dose rates from jacket with FAs for different variants of loading, $\mu \mathrm{kSv} / \mathrm{h}$

\begin{tabular}{|c|c|c|c|c|c|c|c||}
\hline $\begin{array}{c}\text { Variant } \\
\text { of jacket } \\
\text { loading }\end{array}$ & $\begin{array}{c}\text { Distance from } \\
\text { jacket surface, } \\
\mathrm{cm}\end{array}$ & $\mathrm{D}_{\mathrm{n}}$ & $\mathrm{D}_{\mathrm{n}, \gamma}$ & $\mathrm{D}_{\gamma}$ & $\mathrm{D}_{\gamma(\beta)}$ & $\Sigma_{\gamma}$ & $\mathbf{D}_{\Sigma}$ \\
\hline \hline \multirow{4}{*}{$\mathrm{A}$} & 0 & $3.71 \mathrm{E}+1$ & $9.42 \mathrm{E}-2$ & $2.07 \mathrm{E}+1$ & $3.76 \mathrm{E}+0$ & $2.46 \mathrm{E}+1$ & $6.17 \mathrm{E}+1$ \\
& 10 & $3.18 \mathrm{E}+1$ & $7.91 \mathrm{E}-2$ & $1.80 \mathrm{E}+1$ & $3.26 \mathrm{E}+0$ & $2.13 \mathrm{E}+1$ & $5.31 \mathrm{E}+1$ \\
& 50 & $1.98 \mathrm{E}+1$ & $4.67 \mathrm{E}-2$ & $1.17 \mathrm{E}+1$ & $2.11 \mathrm{E}+0$ & $1.39 \mathrm{E}+1$ & $3.37 \mathrm{E}+1$ \\
& 100 & $1.23 \mathrm{E}+1$ & $2.96 \mathrm{E}-2$ & $7.58 \mathrm{E}+0$ & $1.36 \mathrm{E}+0$ & $8.97 \mathrm{E}+0$ & $2.13 \mathrm{E}+1$ \\
& 200 & $5.86 \mathrm{E}+0$ & $1.45 \mathrm{E}-2$ & $3.65 \mathrm{E}+0$ & $6.49 \mathrm{E}-1$ & $4.31 \mathrm{E}+0$ & $1.02 \mathrm{E}+1$ \\
\hline & 0 & $3.33 \mathrm{E}+1$ & $9.77 \mathrm{E}-2$ & $9.95 \mathrm{E}+0$ & $6.97 \mathrm{E}+0$ & $1.70 \mathrm{E}+1$ & $5.03 \mathrm{E}+1$ \\
$\mathrm{~B}$ & 10 & $2.82 \mathrm{E}+1$ & $8.19 \mathrm{E}-2$ & $8.58 \mathrm{E}+0$ & $6.00 \mathrm{E}+0$ & $1.47 \mathrm{E}+1$ & $4.29 \mathrm{E}+1$ \\
& 50 & $1.71 \mathrm{E}+1$ & $4.85 \mathrm{E}-2$ & $5.43 \mathrm{E}+0$ & $3.83 \mathrm{E}+0$ & $9.31 \mathrm{E}+0$ & $2.64 \mathrm{E}+1$ \\
& 100 & $1.11 \mathrm{E}+1$ & $3.13 \mathrm{E}-2$ & $3.74 \mathrm{E}+0$ & $2.65 \mathrm{E}+0$ & $6.42 \mathrm{E}+0$ & $1.75 \mathrm{E}+1$ \\
& 200 & $5.45 \mathrm{E}+0$ & $1.53 \mathrm{E}-2$ & $1.84 \mathrm{E}+0$ & $1.31 \mathrm{E}+0$ & $3.17 \mathrm{E}+0$ & $8.62 \mathrm{E}+0$ \\
\hline & 0 & $3.01 \mathrm{E}+1$ & $9.30 \mathrm{E}-2$ & $9.94 \mathrm{E}+0$ & $6.97 \mathrm{E}+0$ & $1.70 \mathrm{E}+1$ & $4.71 \mathrm{E}+1$ \\
$\mathrm{C}$ & 10 & $2.56 \mathrm{E}+1$ & $7.83 \mathrm{E}-2$ & $8.58 \mathrm{E}+0$ & $6.00 \mathrm{E}+0$ & $1.47 \mathrm{E}+1$ & $4.29 \mathrm{E}+1$ \\
& 50 & $1.55 \mathrm{E}+1$ & $4.66 \mathrm{E}-2$ & $5.43 \mathrm{E}+0$ & $3.83 \mathrm{E}+0$ & $9.31 \mathrm{E}+0$ & $2.48 \mathrm{E}+1$ \\
& 100 & $1.01 \mathrm{E}+1$ & $3.02 \mathrm{E}-2$ & $3.74 \mathrm{E}+0$ & $2.65 \mathrm{E}+0$ & $6.42 \mathrm{E}+0$ & $1.65 \mathrm{E}+1$ \\
& 200 & $4.98 \mathrm{E}+0$ & $1.48 \mathrm{E}-2$ & $1.84 \mathrm{E}+0$ & $1.31 \mathrm{E}+0$ & $3.16 \mathrm{E}+0$ & $8.14 \mathrm{E}+0$ \\
\hline
\end{tabular}


From the above data it follows that the best variant for transportation and storing of pilot MOX FAs in jacket is variant $\mathrm{C}$. This variant provides full jacket loading with 15 uranium FAs and 3 MOX FAs, in so doing the latters are to be positioned in inner row. Shielding effect of outer row filling with uranium FAs (compare variants $\mathrm{A}$ and $\mathrm{B}$ ) is about $23 \%$ (dose rate on jacket surface). With full filling of inner row (three uranium FAs added) dose rate on surface is further reduced by about $7 \%$.

\section{CONCLUSION}

This work has been done to ground from the viewpoint of radiation situation best variant for loading three pilot FAs with MOX fuel based on weapons-grade plutonium into 18-position jacket of inplant transport cask designed for transportation and temporary storage of FAs with fresh fuel.

The calculation study has shown that the most advantageous variant is the arrangement of MOX FAs in inner row of jacket together with three uranium FAs and concurrent filling outer row with 12 uranium FAs. This variant permits reducing dose rate by about $30 \%$ as compared with variant without using uranium FAs, when MOX FAs are solely arranged in inner row of jacket. 


\section{REFERENCES}

1. MOX LTA Fuel Cycle Analyses. Nuclear and Radiation Safety. RRC KI - IPPE. Moscow 2000.

2. А.Л. Кочетков. Программа CARE - расчет изотопной кинетики, радиационных и экологических характеристик ядерного топлива при его облучении и выдержке. Препринт ФЭИ-2431. Обнинск, 1995

3. RSICC DLC-182 "ABBN-90: Multygroup Constant Set for Calculation of Neutron and Photon Radiation Fields and Functionals, Including the CONSYST2 Program".

4. Mynatt F.R., et al. "The DOT III Two-Dimensional Discrete Ordinates Transport Code", Oak Ridge National Laboratory, TN, ORNL-TM-4280 (September, 1973)

5. American National Standard Neutron and Gamma-Ray Flux-to-Dose-Rate Factors. ANSI/ANS-6.1.1-1977 (N666). 


\section{Comments from M. B. Emmett and R. T. Primm III, ORNL, on Shipping Cask Studies with MOX Fuel}

\section{GENERAL NOTES:}

1. Page 5, last paragraph: Typographical error-"base" should be "basis."

2. Page 6, paragraph 1: Typographical error-“the each" should just be "each."

3. Page 6, paragraph 2: It is assumed that "package sets stacks" means stacks of package sets.

4. Page 6, paragraph 4: Change "while coolant density lowering" to "while lowering coolant density."

5. Page 7, paragraph 3: The phrase "gaps volumes" probably should be "gaps' volumes" or "volume of the gaps."

6. Page 7, paragraph 3, bullet 4: Typographical error-"'boric steel" should be "borated steel."

7. Page 7, last paragraph: Typographical error-"cross-sections table" should be "cross-section tables."

\section{SPECIFIC COMMENTS}

1. Page 6: Additional information regarding the description of "decks" used in the storage of fuel at the power plant is desired.

2. Page 7, middle of the page: The phrase "the non-monotonous" should be "strongly spatiallyvarying."

3. Page 8: Typographical error-"multy-group" should be "multigroup."

Page 8, line 1: Typographical error-"physic" should be "physics."

Page 8, paragraph 3: Typographical error-"practically of any complication" should be "practically without complication."

Page 8, paragraph 4: The meaning of "registration zones" should be clarified.

Page 8, paragraph 5, bullet 1: Typographical error_-"absorbtions" should be "absorptions."

Page 9, paragraph 1: It would be easier to understand if the pronoun "one" had not been used as in "MOX one." It is suggested that the author use "MOX fuel pin" instead.

Page 9, paragraph 1: When a sentence starts with a number, the word for the number should be spelled out, as "six" and not " 6. ."

4. Page 9: The weight percentages of the uranium and plutonium isotopes are consistent with the assembly design during the calendar year 2000 but were modified (plutonium isotopes increased) during 2001. However, the value shown in Table 4.1 is acceptably bounding by the 2001 fuel assembly definition.

5. Page 10: It is assumed that the entries " $\mathrm{x} 0.69$ " and " $\mathrm{x} 1.0$ " reflect uncertainties in these parameters.

6. Page 11, last paragraph: A better understanding is achieved by replacing "ensured for package sets location in 4 rows without limitation in width" with the phrase "can be assured by limiting the height of the stacked array to no more than four rows (no limitation in width or breadth)." 
7. Page 11: In the United States, a limitation of a stacking height to four rows is an example of an "administrative" control. While such controls are acceptable and licensable, "inherent, engineered controls" such as safe-by-geometry are preferred.

Page 13, paragraph 1: A better choice of wording would replace "not closed" with either "open" or "unclosed."

Page 13, paragraph 1: Typographical error-Use "assumed to be" instead of "supposed."

Page 13, paragraph 2: Typographical error-"boron acid in current" should be "boric acid in coolant."

Page 13, paragraph 2, last line: Typographical error-"Fa's" should be "FA's."

Page 13, paragraph 4: Typographical error-"increases of" should be "increases by."

Page 14: Typographical error-"meet" should be "meets."

Page 18: Typographical error-The reference to "p. 5.2" should be "Section 5.2."

Page 18: Typographical error-The term "subcriticlity" should be "subcriticality."

8. Page 13, second paragraph: The word "current" should be "coolant."

9. Page 13: Prevention of water densities between 0 and $0.5 \mathrm{~g} / \mathrm{cm}^{3}$ should be discussed. Is a scenario of a "mist" in the pool area plausible?

10. Part 2, Page 5: In Table 1, "circonium" should be "zirconium."

11. Page 6: In Table 3, it is assumed that the number for Group 26 is the minimum value for the energy group. 
ORNL/SUB/00-85B99398V-3

\section{INTERNAL DISTRIBUTION}

$\begin{aligned} 1 . & \text { R. J. Belles } \\ 2-6 . & \text { B. B. Bevard } \\ 7 . & \text { S. M. Bowman } \\ 8 . & \text { J. J. Carbajo } \\ 9 . & \text { M. D. DeHart } \\ 10 . & \text { F. C. Difilippo } \\ 11 . & \text { M. E. Dunn } \\ 12 . & \text { K. Elam } \\ 13 . & \text { R. J. Ellis } \\ 14 . & \text { M. B. Emmett } \\ 15 . & \text { S. E. Fisher } \\ 16 . & \text { C. W. Forsberg } \\ \text { 17-21. } & \text { J. C. Gehin } \\ 22 . & \text { S. Goluoglu } \\ 23 . & \text { S. R. Greene } \\ 24 . & \text { R. F. Holdaway } \\ 25 . & \text { D. Hollenbach } \\ 26 . & \text { C. M. Hopper }\end{aligned}$

27. D. T. Ingersoll

28. M. A. Kuliasha

29. S. B. Ludwig

30. M. P. McGinnis

31. G. E. Michaels

32. D. L. Moses

33. L. J. Ott

34. C. V. Parks

35. W. P. Poore III

36-40. R. T. Primm III

41. B. T. Rearden

42. C. C. Southmayd

43. D. J. Spellman

44. J. C. Wagner

45. R. M. Westfall

46. D. L. Williams, Jr.

47. ORNL Central Research Library

48. ORNL Laboratory Records-RC

\section{EXTERNAL DISTRIBUTION}

49. M. L. Adams, Department of Nuclear Engineering, Texas A\&M University, Zachry 129, College Station, TX 77843

50. D. Alberstein, Los Alamos National Laboratory, P.O. Box 1663, MS-K551, Los Alamos, NM 87545

51. J. B. Briggs, Idaho National Environmental and Engineering Laboratory, P.O. Box 1625-3855, Idaho Falls, ID 83415-3855

52. N. Fletcher, Office of Fissile Materials Disposition, U.S. Department of Energy, NN-63, 1000 Independence Avenue SW, Washington, DC 20585

53. K. Chidester, Los Alamos National Laboratory, P.O. Box 1663, MS-E502, Los Alamos, NM 87545

54. W. Danker, U.S. Department of Energy, NN-62, 1000 Independence Avenue SW, Washington, DC 20585

55. T. Gould, Lawrence Livermore National Laboratory, P.O. Box 808, MS-L186, Livermore, CA 94551

56. L. Jardine, Lawrence Livermore National Laboratory, P.O. Box 808, MS-L166, Livermore, CA 94551

57. A. Kalashnikov, Institute of Physics and Power Engineering, 1 Bondarenko Square, Obninsk, Kaluga Region, Russia 249020 
58. S. L. Passman, Booz-Allen \& Hamilton, 555 13th Street, NW, No. 480E, Washington, DC 20004

59-63. Dr. Alexander Pavlovitchev, Russian Research Center "Kurchatov Institute," Institute of Nuclear Reactors, VVER Division, VVER Physics Department, 123182, Kurchatov Square, 1, Moscow, Russia

64. K. L. Peddicord, Associate Vice Chancellor, Texas A\&M University, 120 Zachry, College Station, TX 77843-3133

65. G. Radulescu, Framatom Cogema Fuels, 1261 Town Center Drive, MS-423, Las Vegas, NV 89143

66. P. T. Rhoads, Office of Fissile Materials Disposition, U.S. Department of Energy, NN-61, 1000 Independence Avenue SW, Washington, DC 20585

67. J. Thompson, Office of Fissile Materials Disposition, U.S. Department of Energy, NN-61, 1000 Independence Avenue SW, Washington, DC 20585

68. F. Trumble, Westinghouse Savannah River Company, Building 730R, Room 3402, WSRC, Aiken, SC 29808

69. R. H. Clark, Duke/Cogema/Stone \& Webster, 400 South Tryon Street, WC-32G, P.O. Box 1004, Charlotte, NC 28202

70. S. Nesbit, Duke/Cogema/Stone \& Webster, 400 South Tryon Street, WC-32G, P.O. Box 1004, Charlotte, NC 28202

71. M. S. Chatterton, Office of Nuclear Reactor Regulation, U.S. Nuclear Regulatory Commission, MS O10B3, Washington, DC 20555-0001

72. R. W. Lee, Office of Nuclear Reactor Regulation, U.S. Nuclear Regulatory Commission, MS O10B3, Washington, DC 20555-0001

73. U. Shoop, Office of Nuclear Reactor Regulation, U.S. Nuclear Regulatory Commission, MS O10B3, Washington, DC 20555-0001

74. Nagao Ogawa; Director and General Manager; Plant Engineering Department; Nuclear Power Engineering Corporation; Shuwa-Kamiyacho Building, 2F; 3-13, 4-Chome Toranomon; Minato-Ku, Tokyo 105-0001, Japan

75. Dr. Kiyonori Aratani; Surplus Weapons Plutonium Disposition Group; International Cooperation and Nuclear Material Control Division; Japan Nuclear Cycle Development Institute; 4-49 Muramatsu, Tokai-mura, Naka-gun, Ibaraki-ken, Japan

76. Boris E. Volkov; Head of Division; EDO Gidropress; 21 Ordzhonikidze Street; Podolsk, Moscow District, Russia 142103

77. Dr. Alexandre Ermolaev; Balakovo Nuclear Power Plant, Saratov Region, Balakovo-26, Russia, 413866 